\title{
Climate Change Impacts on Water Resources of the Largest Hydropower Plant Reservoir in Southeast Brazil
}

\author{
Carlos R. Mello ${ }^{1, *(1)}$, Nayara P. A. Vieira ${ }^{1}$, Jorge A. Guzman ${ }^{2}$, Marcelo R. Viola ${ }^{1}{ }^{\circledR}$, Samuel Beskow ${ }^{3}$ \\ and Lívia A. Alvarenga ${ }^{1}$ \\ 1 Water Resources Department, Universidade Federal de Lavras, Lavras 37200-900, MG, Brazil; \\ nayara_pav@hotmail.com (N.P.A.V.); marcelo.viola@ufla.br (M.R.V.); livia.aalvarenga@ufla.br (L.A.A.) \\ 2 Department of Agricultural and Biological Engineering, College of ACES, University of Illinois at \\ Urbana-Champaign, Urbana, IL 61801, USA; jag@illinois.edu \\ 3 Center for Technological Development, Water Resources, Universidade Federal de Pelotas, \\ Pelotas 96015-610, RS, Brazil; samuelbeskow@gmail.com \\ * Correspondence: crmello@ufla.br
}

Citation: Mello, C.R.; Vieira, N.P.A.; Guzman, J.A.; Viola, M.R.; Beskow, S.; Alvarenga, L.A. Climate Change Impacts on Water Resources of the Largest Hydropower Plant Reservoir in Southeast Brazil. Water 2021, 13, 1560. https://doi.org/10.3390/ w13111560

Academic Editor: Tom Ball

Received: 30 April 2021

Accepted: 28 May 2021

Published: 31 May 2021

Publisher's Note: MDPI stays neutral with regard to jurisdictional claims in published maps and institutional affiliations.

Copyright: (c) 2021 by the authors. Licensee MDPI, Basel, Switzerland. This article is an open access article distributed under the terms and conditions of the Creative Commons Attribution (CC BY) license (https:// creativecommons.org/licenses/by/ $4.0 /)$.

\begin{abstract}
Approximately 70\% of all the electric energy produced in Brazil comes from hydropower plants. In this context, the Grande River Basin (GRB) stands out in Brazil. Some studies have been carried out to investigate the impacts of climate change in tropical regions to support water resources' management and planning. This study aims to project the changes in the runoff that feed the Furnas Hydropower Plant (FHP) reservoir (GRB-Furnas basin), the largest and most important facility in Southeast Brazil. The lavras simulation of hydrology model (LASH) was used to project the impacts on runoff and hydrological droughts over the century in GRB-Furnas. The regional climate models (RCMs) Eta-HadGEM-ES, Eta-MIROC5, and Eta-CanESM2 forced the LASH model from 2007 to 2099, taking the representative concentration pathways (RCPs) 4.5 and 8.5. LASH simulated the runoff adequately for the baseline period (1961-2005) using the RCMs' outputs. A noticeable reduction in precipitation was identified in the wet season, especially in the 2007-2040 period for RCP4.5 and in the 2071-2099 period for RCP8.5. As a result, a significant reduction in the runoff, mainly in the baseflow, and an increase in droughts' severity were projected throughout the XXI Century, which may compromise the water security to the FHP reservoir.
\end{abstract}

Keywords: hydrological simulation; regional climate models; climate change; hydrological impacts

\section{Introduction}

The availability of water resources is determined by the complex interaction of natural and human-driven processes occurring along the critical zone. Changes in climate or human activity can result in contrasting hydrological responses with desired or undesired local to regional impacts. Among these changes, developing countries have been more vulnerable to the negative impacts of actual and projected changes in climate [1,2], including the rapid increase of economic and social inequality and the elevated risk of critical infrastructure failure.

In Brazil, hydropower plants are responsible for approximately $70 \%$ of the country's electric energy production, making this source highly susceptible to climate changes. These impacts are more evident in the dry season, reducing the hydroelectricity production in hydropower plants as their reservoirs depend on precipitation in the rainy season for hydrological regulation. Changes in the rainy season pattern can threaten the reservoirs' operation, thereby jeopardizing the hydropower generation [3-6].

Grande river is a tributary of the Parana river basin, which is the most important hydrograph region for hydroelectricity in Brazil [6]. The Grande River Basin (GRB) is in Southeastern Brazil, with headwaters in the states of São Paulo and Minas Gerais. This basin is relevant for the Brazilian hydropower system as cascades of eleven hydropower 
plants are directly operating across the Grande river. Furnas hydropower plant (FHP) reservoir's primary function is to regulate downstream water flow to secure full generation capacity across the cascade of hydropower plants [6-8]. Therefore, its operation is highly dependent on the hydro-climate response over the basin draining into Furnas reservoir [6].

Previous studies regarding climate change impacts on the hydrology of the upper Grande river basin projected contradictory behavior and incomplete analysis of the runoff behavior. The Eta-HadCM3 [8], Eta-HadGEM2-ES [5], and Eta-MIROC5 [5] regional climate models (RCMs) were applied in this region, covering approximately $16,000 \mathrm{~km}^{2}$, i.e., only $30 \%$ of the basin that flows to the FHP reservoir. These studies evaluated neither the impacts of climate changes using the RCMs on the occurrence of droughts nor the impacts over the indicators derived from frequency flow duration curves and water balance.

Because of the relevance of the GRB and FHP reservoir for the Brazilian hydropower system, in addition to the inconclusive insights for the region related to the impacts of climate changes on water resources, this study sought to (i) model the runoff of the GRB upstream Furnas, covering the entire basin (GRB-Furnas); and (ii) assess the impacts of Climate change up to the end of the century. Three RCMs were used to assess the impacts on water resources of the basin, focusing on the runoff into FHP reservoir and droughts' projection. The main novelty of this study was the evaluation of the capability of three RCMs (Eta-HadGEM2-ES, Eta-MIROC5, and Eta-CanESM2) coupled with a wellestablished hydrological model for tropical basins (LASH) to project droughts over the basin controlling the hydrology of the largest and the most important reservoir in southeastern Brazil. The long-term objective of this study was to enhance decision support tools for policymakers to advance in planning and management of impacts and identify potential environmental and water resources conflicts that may arise under future climate variability and change projections.

\section{Materials and Methods}

\subsection{Study Area}

This study was developed in the GRB upstream Furnas hydropower plant (GRBFurnas), southeast Brazil, accounting for an area of approximately $52,000 \mathrm{~km}^{2}$. Figure 1 illustrates the GRB location within the Brazilian territory and the network of rain gauges and weather stations used in this study to assess the hydrologic response at the Furnas Hydropower Plant. The water resource of the GRB-Furnas is fundamental for the country as the Grande river supplies a cascade of seven downstream hydropower plants directly installed along its course. FHP has the largest reservoir in southeastern Brazil, responsible for the hydrological regime of the entire GRB. Its operation aims to maintain the run-ofriver characteristic of the downstream reservoirs and, consequently, their power generation capacity throughout the year [6].

There are two Köppen climate types in GRB-Furnas, Cwa and Cwb, both temperate climates $(\mathrm{C})$, with dry winters and rainy summers $(\mathrm{w})$, and the average temperatures of the hottest month (January or February) are $\geq 22{ }^{\circ} \mathrm{C}$ (a) and $<2{ }^{\circ} \mathrm{C}(\mathrm{b})$. The hydrological year is well defined between October and September in the following year [8]. Overall, the mean maximum and minimum temperatures are $22{ }^{\circ} \mathrm{C}$ and $8{ }^{\circ} \mathrm{C}$, respectively, and the mean annual precipitation is approximately $1500 \mathrm{~mm}$ [9]. 
(a)

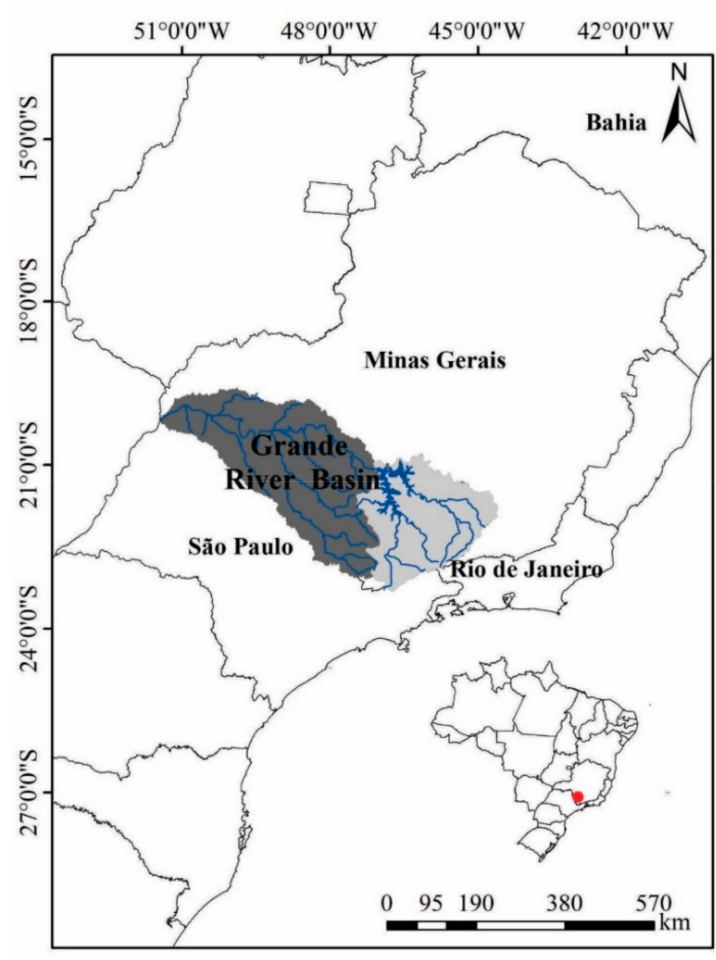

(b)

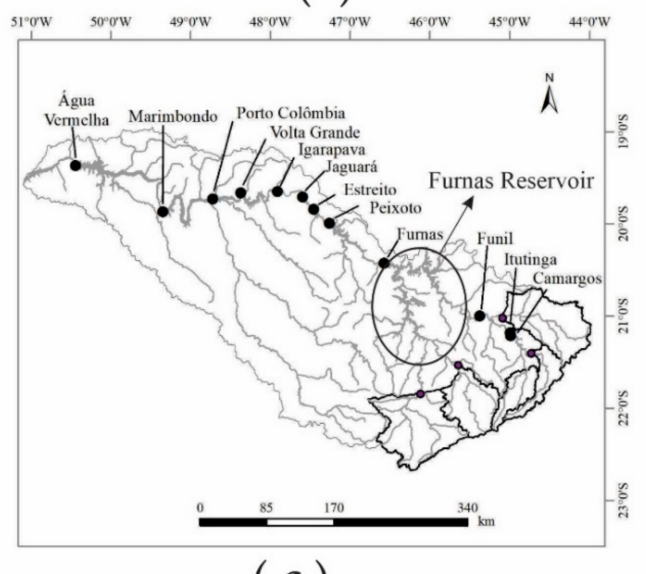

(c)

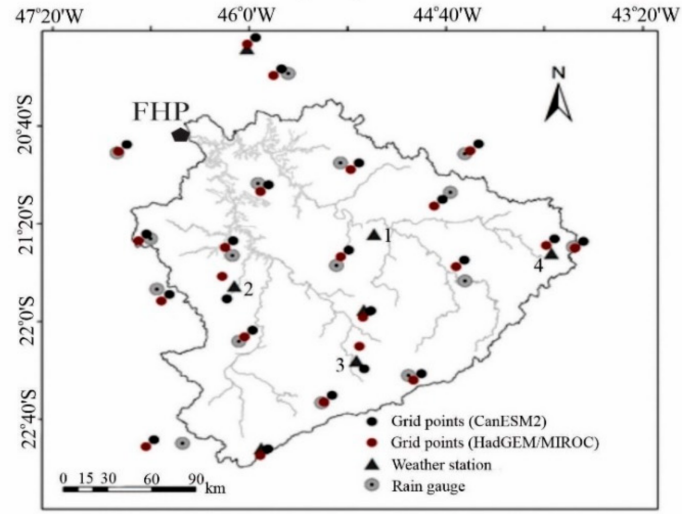

Figure 1. (a) The geographical location of the Grande River Basin (GRB)-Furnas; (b) Grande river basin with the cascade of hydropower plants and the main headwater sub-basins; (c) the GRB-Furnas basin, rain gauges, weather stations, and grid points of the regional climate models (RCMs) used in this study.

\subsection{The Lavras Simulation of Hydrology Model (LASH)}

The LASH model was developed to simulate streamflow in data-scarce basins [10]. Since its first version, LASH has continuously been improved by implementing autocalibration [11], coupling with the GIS environment, and providing different levels of spatial discretization (grid cells, sub-watersheds, and hydrological response units) [12-14].

LASH is a distributed hybrid model that combines conceptual with physically-based principles for long-term deterministic hydrological simulations. It is structured based on three runoff modules: (i) direct surface runoff (DSUP), which is based on the modified CN method [15]; (ii) sub-surface runoff (DSS); and (iii) baseflow (DB), both based on the Brooks and Corey equation for porous media hydraulic properties [16]. LASH converts the runoff components into streamflow by considering the time lag of the modules' flows (also known as "reservoirs"). For streamflow routing in the watercourses, the Musk-ngum-Cunge linear method is applied [17]. The Penman-Monteith equation [18] was used to calculate evapotranspiration, considering aerodynamic and stomatal conductance of the land uses and a soil moisture threshold to determine the actual evapotranspiration [19]. LASH has been successfully applied to many Brazilian watersheds under different geomorphological contexts $[8,10-14,20]$.

\subsubsection{Weather and Hydrological Datasets and Basic Maps}

The weather datasets used for calibration and validation of the LASH model were obtained from the Hydrological Information System (HidroWeb)/National Water Agency (ANA) and National Institute of Meteorology (INMET/BDMEP) (Figure 1c), both covering 
a period of 18 years (from 1990 to 2007). The assessed variables were the daily values of rainfall, maximum and minimum temperatures, solar income radiation, relative humidity, and wind speed. Except for rainfall, the remaining variables were used to calculate the evapotranspiration according to the Penman-Monteith equation [18].

The streamflow data used for LASH calibration and validation were obtained from the Electric System's National Operator (ONS). These data correspond to naturalized streamflows determined by the ONS, i.e., the Grande river's daily streamflows without the effect of anthropogenic activities, such as reservoir operation and water withdrawal for human supply and irrigation consumption [21]. These datasets are calculated based on a rebuilding process that uses the ensemble of 96 stochastic models to predict daily streamflows in each hydropower plant of the country [22]. The ONS considered these datasets during the planning of the hydropower plants for the short and middle terms.

The LASH model requires maps of soil and land use (Figure 2a,b). The land-use map was derived based on LANDSAT- 8 with supervised classification through the maximum likelihood classifier [14]. The land uses are pasture (40.76\%), Atlantic forest $(25.07 \%)$, agriculture (18.17\%), Brazilian savanna-Cerrado $(9.88 \%)$, water bodies $(2.57 \%)$, and eucalyptus $(2.45 \%)$. Other land-uses, such as urban areas $(0.91 \%)$ and bare soils $(0.19 \%)$, were less pronounced. The soil map is on a scale of 1:650,000, and the classes are Latosols (42.96\%), Argisols (25.76\%), Cambisols (23.08\%), Litholic Neosol (3.27\%), and others less significant (4.93\%) [14]. The basin's elevation varies from 655 at Furnas dam to more than $1550 \mathrm{~m}$, with summits higher than $2100 \mathrm{~m}$ [14], in Mantiqueira Range, which is the water divisor of the basin in the border between Minas Gerais and São Paulo states (Figure 2c).

(a)

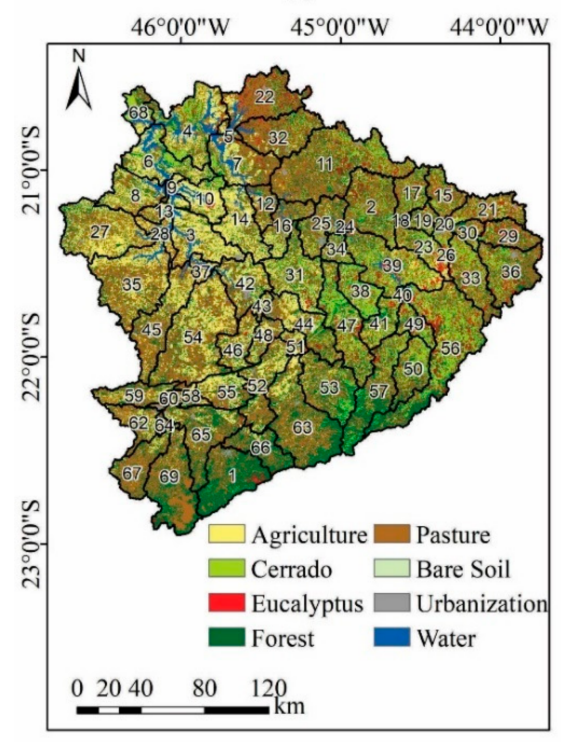

(b)

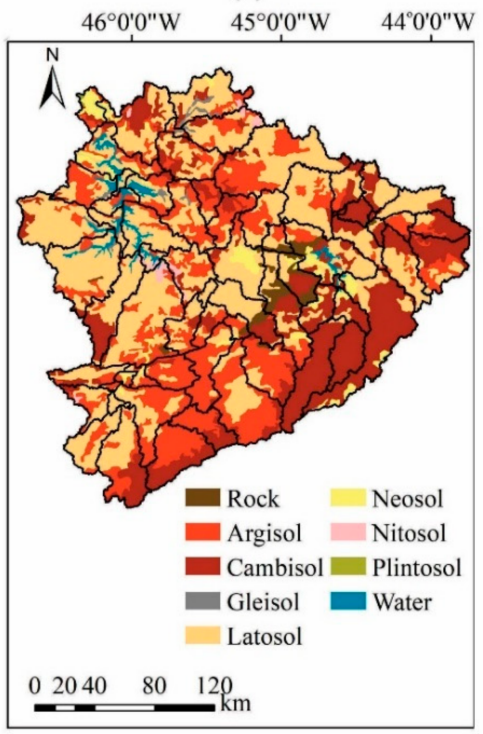

(c)

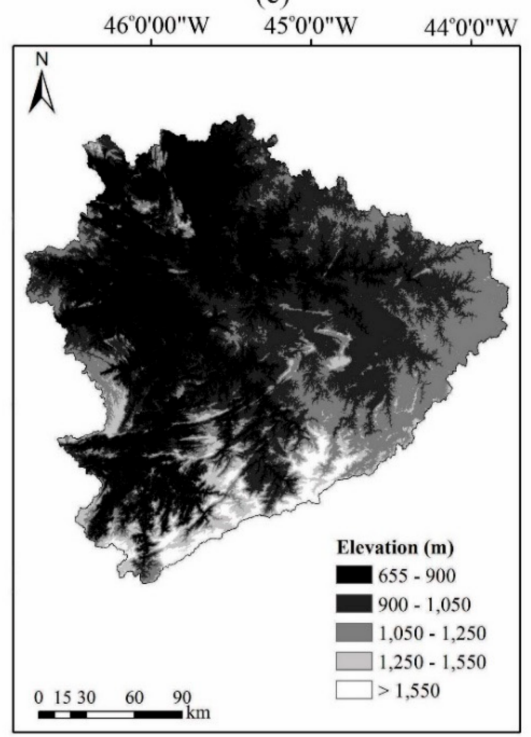

Figure 2. (a) Land-use map with the sub-watersheds used in the Lavras simulation of hydrology (LASH) calibration; (b) soil map; (c) the digital elevation model of the GRB-Furnas.

\subsubsection{Calibration and Validation of the LASH Model}

For calibration and validation of the LASH model, daily streamflow and weather data were obtained from 1990 to 2007 for GBR-Furnas. Both datasets are the most robust existing data for the basin in this period, with less than $10 \%$ of data gaps. LASH was calibrated between 1990 and 2000 and validated between 2001 and 2007. The years 1990 and 1991 were used for the model's warmup. The performance of the model was evaluated based on the statistical indicators Nash-Sutcliffe coefficient (NSC) [23], the $\log$ (NSC) coefficient [23], and the percentage ratio between observed and calculated volumes $(\Delta \mathrm{V})[8]$.

In the LASH version used in this study, five parameters were calibrated by the following [14]: (i) the initial abstraction coefficient ( $\lambda$ ); (ii) hydraulic conductivity of the 
sub-surface reservoir $\left(\mathrm{K}_{\mathrm{SS}} ; \mathrm{mm}^{\mathrm{day}}{ }^{-1}\right)$; (iii) hydraulic conductivity of the groundwater reservoir $\left(\mathrm{K}_{\mathrm{B}} ; \mathrm{mm} \mathrm{day}^{-1}\right)$; (iv) a routing parameter for the overland flow $\left(\mathrm{C}_{\mathrm{SUP}}\right)$; and (v) a routing parameter for the sub-surface flow $\left(\mathrm{C}_{\mathrm{SS}}\right)[8,10,12]$. For this purpose, the NashSutcliffe coefficient (NSC) was the objective function, and the calibration was distributed by sub-basins (Figure 2a), according to the HRUs defined for the GRB-Furnas (Table 1) [14].

Table 1. Hydrological response units (HRUs) and respective LASH calibrated parameters for the Grande River Basin (GRB)-Furnas [14].

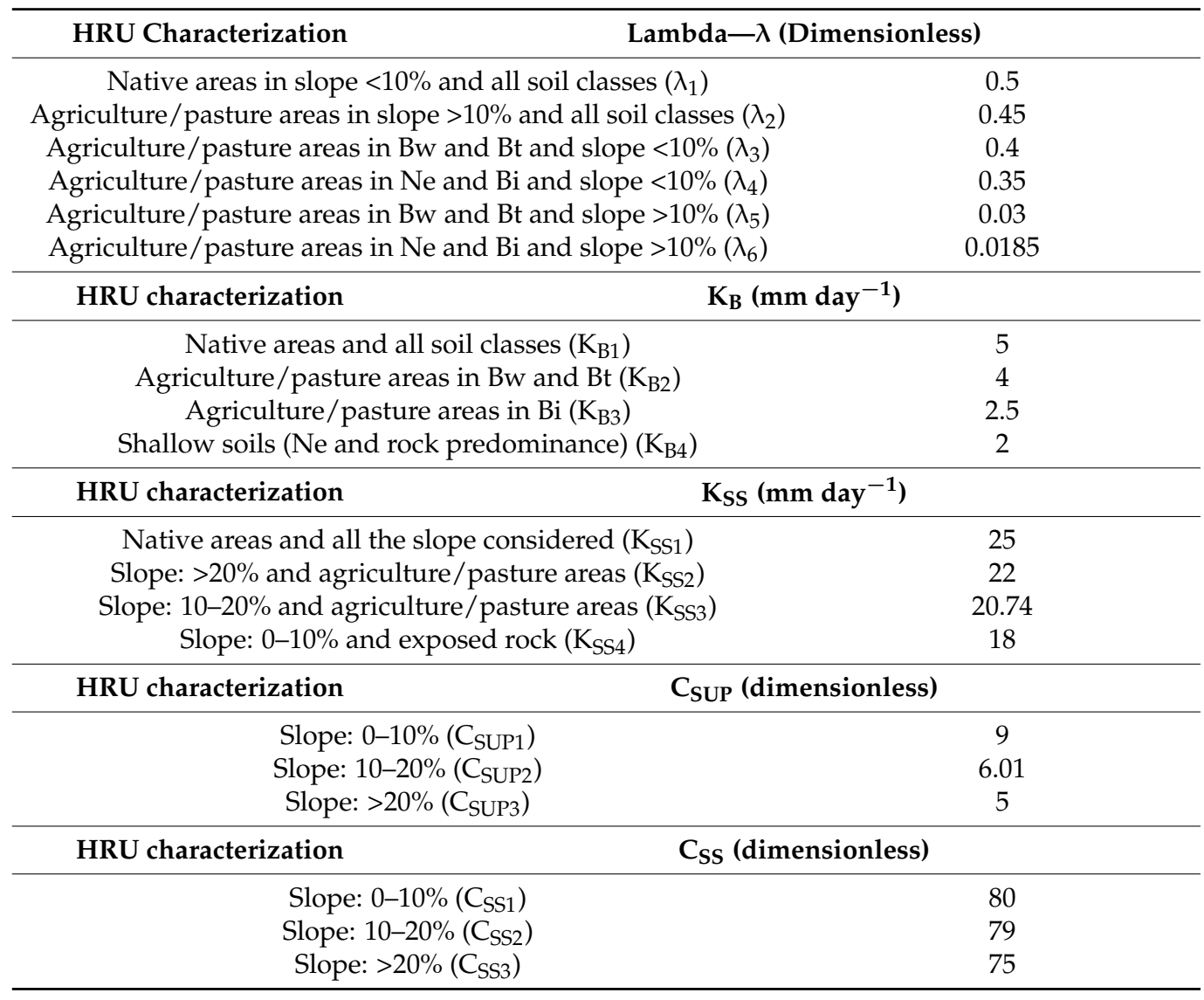

\subsection{Climate Change Projections}

Before the assessment of the climate change projections, the temporal trend of the long-term series of precipitation and evapotranspiration in the rainy period for the four weather stations with datasets available in the GRB-Furnas (Figure 1c: 1-Lavras, $918 \mathrm{~m}$; 2-Machado, $870 \mathrm{~m}$; 3-São Lourenço, $953 \mathrm{~m}$; 4-Barbacena, $1126 \mathrm{~m}$ ) were tested by means of the Mann-Kendall test $(\alpha=0.05)$. This assessment is relevant to evaluate if climate change has affected the studied region in the last 58 years as well as possible connections with its hydrological behavior.

The Intergovernmental Panel on Climate Change (IPCC) has driven the scientific efforts on climate change impacts and proposed mitigations and adaptions [1]. The most common approach to assess climate change impacts is identifying changes in precipitation and temperature and then in the runoff regime [24-26].

The main tools used to project climate scenarios are the global circulation models (GMCs). Their outputs are widely used to study the impacts caused by changes in climate [27-29]. However, GCMs do not have the spatial resolution required to meet the runoff studies on a regional/basin scale. Therefore, the GCMs are coupled with regional climate models (RCMs) for downscaling the outputs in a compatible resolution with hydrological models, allowing for reliable simulations. In South America, the HadGEM2-ES, 
MIROC5, and CanESM2 GCMs, downscaled by the Eta/CPTEC model, have simulated the climate in a $20 \mathrm{~km}$ spatial resolution [30,31].

The GCMs' simulations are published in the 5th Assessment Report (AR5) of the Intergovernmental Panel on Climate Change (IPCC). The models were calibrated and run considering different greenhouse gas concentrations and radiative forcing scenarios, known as representative concentration pathways (RCPs). The most common radiative scenarios used for simulations in South America have been $4.5 \mathrm{~W} \mathrm{~m}^{-2}$ and $8.5 \mathrm{~W} \mathrm{~m}^{-2}$, a stabilization scenario and a high greenhouse gas concentration scenario, respectively [31,32]. These scenarios, known as RCP4.5 and RCP8.5, correspond to an average increase in global temperature ranging from 1.1 to $2.6^{\circ} \mathrm{C}$, and from 2.6 to $4.8^{\circ} \mathrm{C}$, respectively, for the 2081-2100 period with respect the baseline 1986-2005 observations.

The impacts on runoff were estimated according to the hydrological simulations. LASH was forced by climate projections from the HadGEM2-ES, MIROC5, and CanESM2 global circulation models (GCM). The outputs of the GCMs were dynamically downscaled by the Eta/CPTEC model [33], from which the GCMs were called regional climate models (RCMs). Details on these GCMs can be found in [34-36]. The RCMs' projections were generated by CPTEC/INPE and made available on the "PROJETA" Platform (https:/ / projeta.cptec.inpe.br/\#/dashboard) (2 March 2018) for the baseline period (1961-2005) and throughout the XXI Century. The climate projections were divided into three periods (i.e., time slices) (2007-2040; 2041-2070; and 2071-2099), two RCPs (4.5 and 8.5), and a $20 \mathrm{~km}$ spatial resolution $[31,32,37]$. The weather variables used to force the LASH model were precipitation, maximum and minimum temperatures, income solar radiation, relative humidity, and wind speed.

The procedure used for simulation of the hydrological impacts was adapted from $[38,39]$. The RCMs' outputs for the baseline and RCPs 4.5 and 8.5 were obtained in a grid box, taking the nearest grid point of each of the 15 rain gauges and 6 meteorological stations applied to calibrate the LASH model (Figure 1c).

Nevertheless, the weather variables from the RCMs may present systematic errors owing to the numerical procedures used in the models, making it necessary to remove them before forcing the hydrological model [40-43]. The correction of these systematic errors was implemented, fitting a linear regression between the mean monthly observed and projected weather variables to the baseline [43].

\subsection{Assessment of the Hydrological Impacts}

The assessment of the impacts was firstly carried out considering the sensitivity analysis. This assessment was based on changes in the average runoff resulting from climate projections of average precipitation and temperature. First, the model was assessed by quantifying the deviation in mean runoff from the RCMs' simulation and in the baseline period (1961-2005) on a monthly basis. After this validation, changes in runoff were investigated on the basis of the LASH simulations forced by the climate projections derived from the RCMs, RCPs, and per time slice.

The impacts were further evaluated by analyzing changes (\%) in the indicators extracted from the flow duration curve (FDC), which were $\mathrm{Q}_{99 \%}, \mathrm{Q}_{95 \%}, \mathrm{Q}_{90 \%}, \mathrm{MiSI}, \mathrm{Q}_{80 \%}$, $\mathrm{Q}_{50 \%}, \mathrm{Q}_{20 \%}, \mathrm{Q}_{10 \%}, \mathrm{Q}_{5 \%}, \mathrm{Q}_{1 \%}$, and MaSI. MiSI is an indicator that represents the average of the daily streamflow values with an exceedance frequency greater than $95 \%$, basically the minimum daily streamflow values. The MaSI corresponds to the average of the daily streamflow values with a frequency lower than $5 \%$, i.e., the highest daily streamflow values. The baseflow behavior could be analyzed by evaluating the streamflow values corresponding to the frequencies greater than $80 \%$ and the MiSI indicator. All the changes were calculated with respect to the baseline.

In addition to these assessments, the hydrological droughts were also studied. The Standardized Streamflow Index (SSFI) was studied considering the RCMs' outputs, forcing the LASH model for the baseline, and then projected throughout the century. SSFI is calculated by fitting the gamma probability function (GPF) on the accumulated non- 
exceedance frequency of the stationarity historical series and then applying the Gauss distribution inverse, thus resulting in the SSFI values. SSFI is classified as extremely dry (ED) (SSFI $\leq-2.0)$, severely dry (SD) $(-2.0<$ SFFI $\leq-1.5)$, moderately dry (MD) $(-1.5<\mathrm{SSFI} \leq-1.0)$, normal $(\mathrm{N})(-1.0<\mathrm{SSFI} \leq 1)$, moderately wet $(\mathrm{MW})(1.0<\mathrm{SSFI} \leq 1.5)$, very wet $(\mathrm{VW})(1.5<\mathrm{SSFI} \leq 2.0)$, and extremely wet $(\mathrm{EW})(\mathrm{SSFI} \geq 2.0)[44]$.

\section{Results}

\subsection{Basic Hydrology of the Main Sub-Basins of the Upstream Furnas Reservoir}

The five main sub-basins upstream of the Furnas reservoir are Aiuruoca, Grande, Mortes, Verde, and Sapucaí, which cover approximately $60 \%$ of the drainage area into the reservoir (Figure 1b). These fluviometric gauges are unique, with consistently observed datasets upstream of the Furnas reservoir. Considering the studied period (1990-2007), for which there are no gaps, Figure 3 presents the temporal behavior of the daily streamflows observed in the cited sub-basins. Table 2 summarizes the hydrological indicators used to assess the time series consistency while characterizing the average behavior of the main hydrological components of the water balance in these sub-basins.

(a)

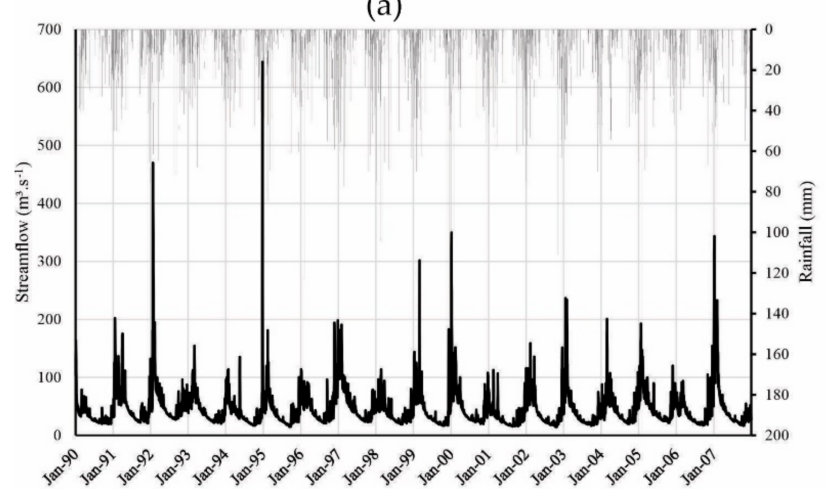

(c)

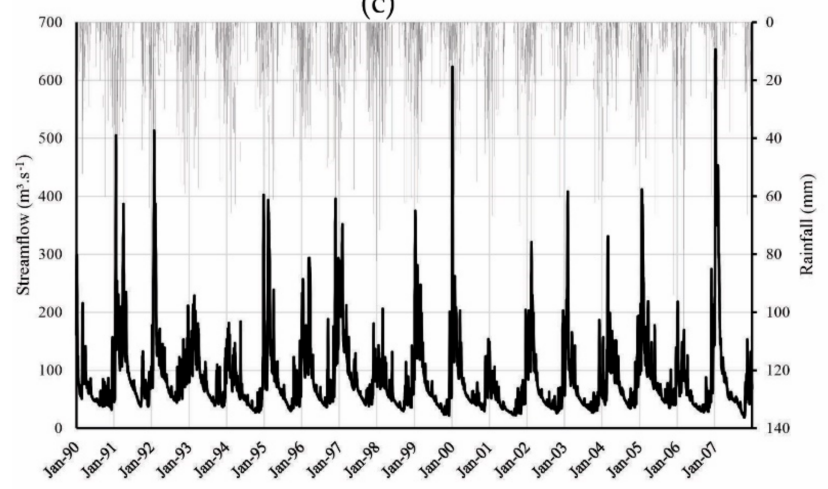

(e)

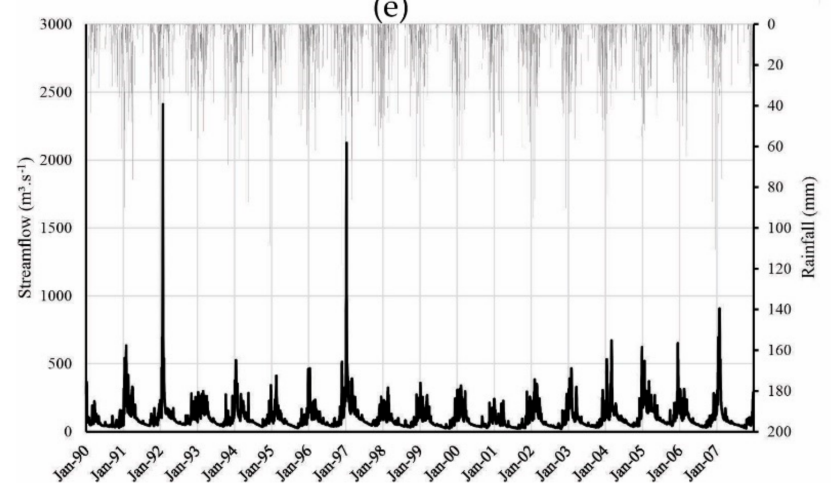

(b)

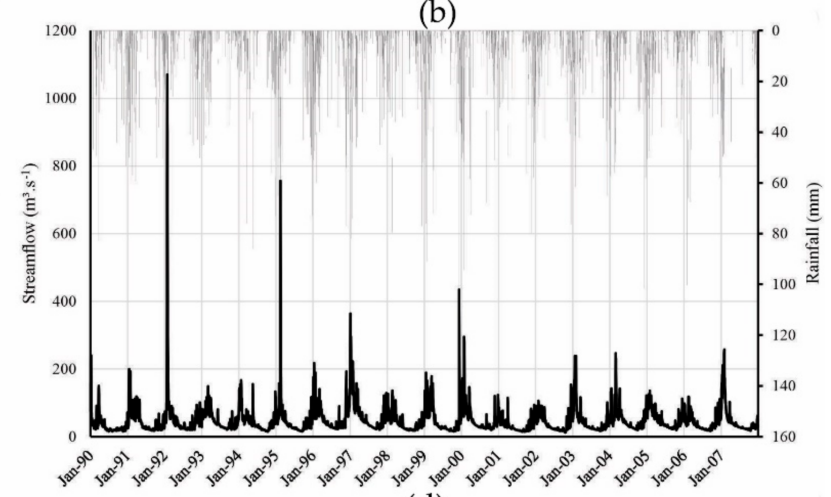

(d)

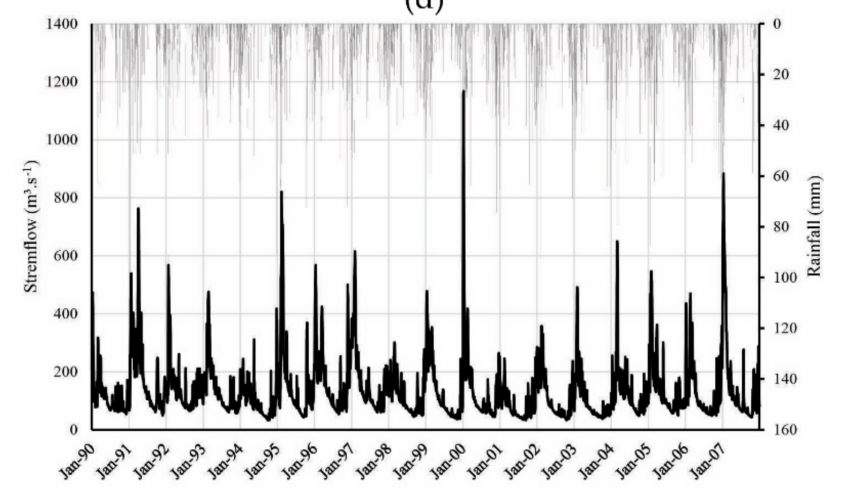

Figure 3. Observed hydrographs in the main sub-basins upstream of the Furnas reservoir: (a) Aiuruoca; (b) Grande; (c) Verde; (d) Sapucaí; and (e) Mortes. 
Table 2. Basic hydrological indicators for the main sub-basins upstream of the Furnas reservoir with fluviometric gauges.

\begin{tabular}{ccccccc}
\hline Sub-Basin & $\mathbf{R}(\mathbf{m m})$ & $\mathbf{P}(\mathbf{m m})$ & ET $(\mathbf{m m})$ & $\mathbf{B}(\mathbf{m m})$ & $\mathbf{C}$ & $\mathbf{B} / \mathbf{R}$ \\
\hline Aiuruoca & 619.3 & 1414.3 & 795.0 & 421.1 & 0.438 & 0.680 \\
\hline Grande & 640.0 & 1468.8 & 828.8 & 409.6 & 0.436 & 0.640 \\
\hline Verde & 544.5 & 1358.1 & 813.6 & 310.4 & 0.401 & 0.570 \\
\hline Sapucaí & 476.3 & 1324.7 & 848.4 & 252.4 & 0.360 & 0.530 \\
\hline Mortes & 362.9 & 1220.0 & 857.1 & 199.6 & 0.297 & 0.550 \\
\hline
\end{tabular}

\subsection{Calibration and Validation of the LASH Model}

The LASH model's calibration for the GRB-Furnas basin was conducted in daily and monthly time steps between 1990 and 2007. The precision statistics used to appraise the model are presented in Table 3.

Table 3. Precision statistics for the calibration and validation of the LASH model to the GRB-Furnas basin. NSC, NashSutcliffe coefficient.

\begin{tabular}{ccccc}
\hline Precision Statistic & Calibration (Daily) & Validation (Daily) & Calibration (Monthly) & Validation (Monthly) \\
\hline NSC & 0.86 & 0.77 & 0.89 & 0.85 \\
Log (NSC) & 0.83 & 0.76 & 0.86 & 0.83 \\
SV $(\%)$ & 2.16 & 11.44 & 2.00 & 12.00 \\
\hline
\end{tabular}

In the GRB-Furnas basin case, hydrographs estimated by LASH were in good agreement with observations during the calibration and validation periods for the runoff's seasonal variation, runoff peaks, and the water balance (Table 3, Figure 3). Figure 4 depicts the observed hyetographs and hydrographs and the daily and monthly hydrographs estimated by LASH to GRB-Furnas.

(a)
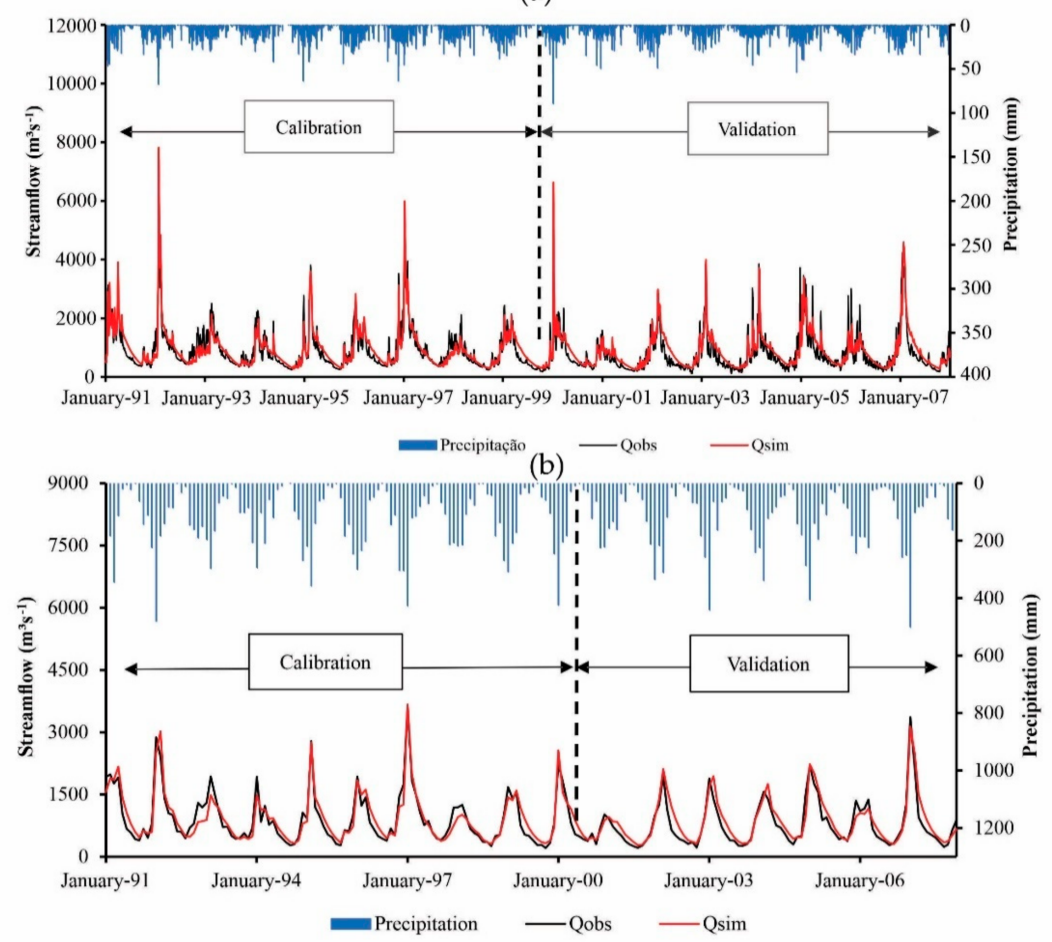

Figure 4. Observed and estimated daily (a) and monthly (b) hydrographs and respective hyetographs in the GRB-Furnas basin for calibration and validation of the LASH model. 


\subsection{Trend Behavior of the Precipitation and Evapotranspiration Long-Term Series in GRB-Furnas}

Figure 5 depicts the temporal trend behavior of the precipitation and evapotranspiration for the four weather stations within the GRB-Furnas considering the rainy period, which is more relevant in hydrological terms. The Mann-Kendall test for each one of the long-term series is also presented.

a)
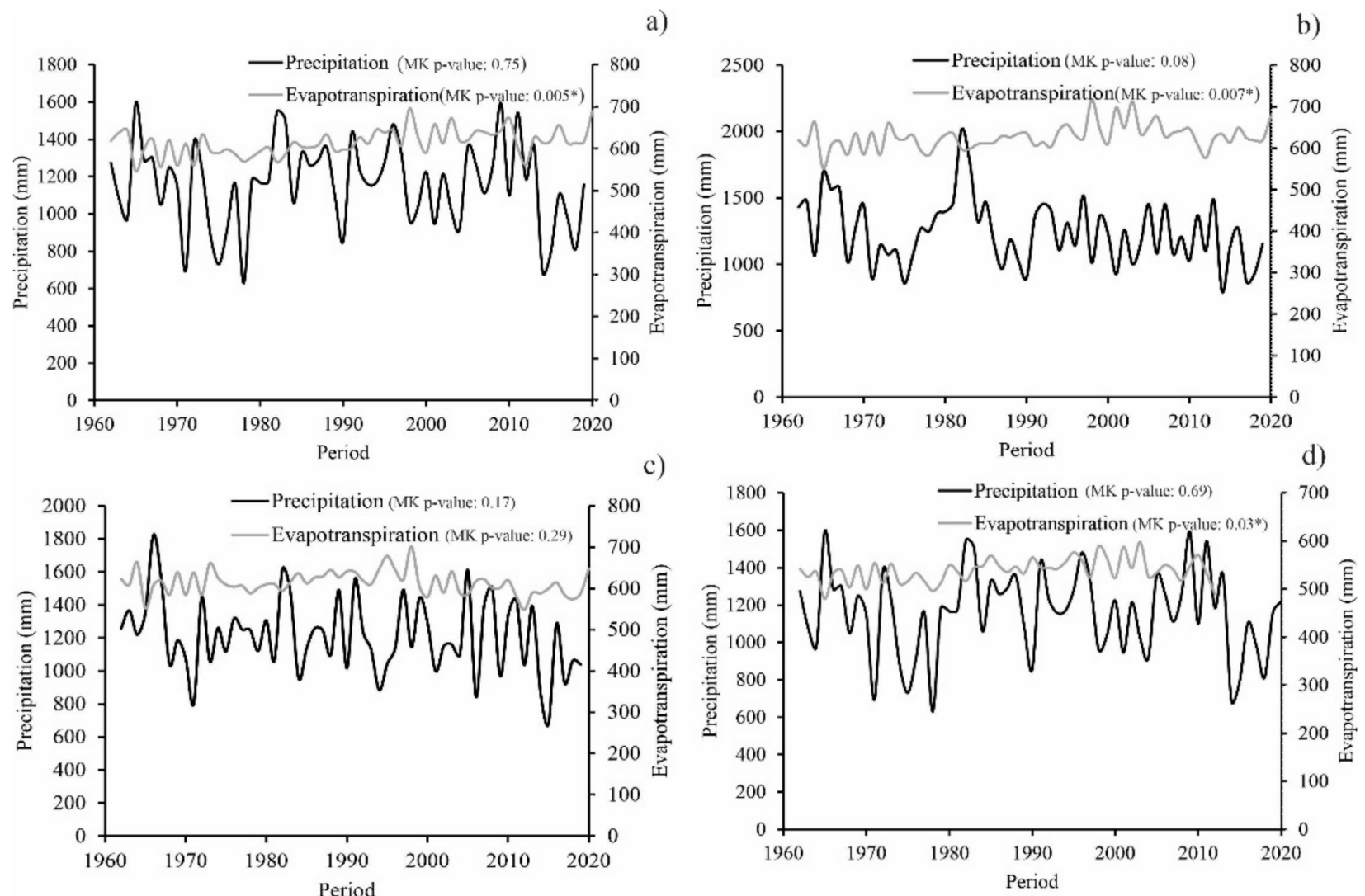

Figure 5. Temporal behavior of precipitation and evapotranspiration in the rainy period for the four weather stations in GRB-Furnas and respective Mann-Kendall test results. (a) Lavras (number 1-Figure 1); (b) Machado (number 2-Figure 1); (c) São Lourenço (number 3-Figure 1); (d) Barbacena (number 4-Figure 1).

\subsection{Climatic Change Projections to the GRB-Furnas Basin, Southeastern Brazil}

In this section, the ensemble of monthly precipitation, minimum and maximum monthly temperatures, and respective ranges projected by the RCMs were detailed concerning the baseline period after removing the systematic errors (Figure 6). Changes in the precipitation (\%) were analyzed to assess the impacts of the projected climate change in regards to the following: (a) deviation in the average maximum, (b) deviation in the minimum temperatures $\left({ }^{\circ} \mathrm{C}\right)$, and (c) deviation between the baseline and projected precipitation by the RCMs (i.e., RCP4.5 and RCP8.5) and per time slice. The projections indicated a significant reduction of approximately $20 \%$ in the mean monthly precipitation during the wet season (December, January, February, March, and April), a slight increase in the dry season (May, June, July, August), and a substantial increase in November. 

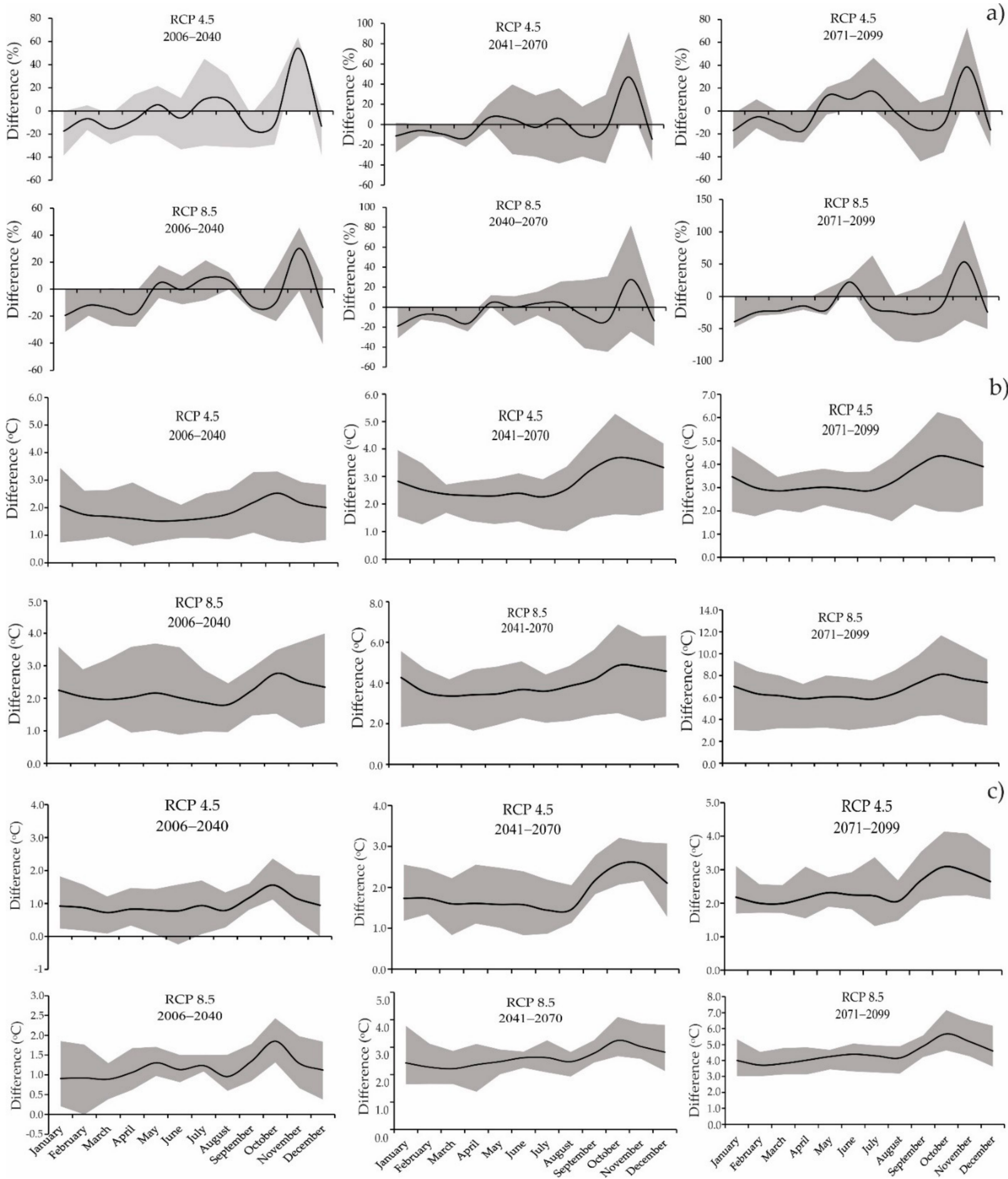

Figure 6. Changes in the monthly average precipitation (\%) (a) and maximum (b) and minimum (c) temperatures (ensemble, black line) and respective ranges simulated by the RCMs under RCP4.5 and RCP8.5 for the GRB-Furnas throughout the XXI Century.

\subsection{Projections of the Hydrological Impacts in the GRB-Furnas Basin}

3.5.1. Runoff Sensitivity to the Precipitation and Temperature Simulated by the RCMs

Runoff sensitivity to the RCMs was studied using the average monthly values and respective average precipitation and temperature derived from RCMs for their baseline. The changes in the runoff $(\Delta Q=$ observed - simulated) were assessed as a function of the changes in precipitation $(\Delta \mathrm{P})$ and temperature $(\Delta \mathrm{T})$. Regressions were fit- 
ted for RCP4.5 $\left(\Delta \mathrm{Q}=-86.29+0.392 \cdot \Delta \mathrm{P}^{*}-3.87 \cdot \Delta \mathrm{T}^{\mathrm{ns}}\left(\mathrm{R}^{2}=0.929\right)\right)$ and for RCP8.5 $\left(\Delta \mathrm{Q}=-15.64+0.57 \cdot \Delta \mathrm{P}^{*}+15.38 \cdot \Delta \mathrm{T}^{*}\left(\mathrm{R}^{2}=0.974\right)\right)$. In $\mathrm{RCP} 4.5, \Delta \mathrm{Q}$ was not significant $(p<0.05)$ to $\Delta \mathrm{T}$, which means that only $\Delta \mathrm{P}$ explains $\Delta \mathrm{Q}$, with a rate of $-7.5 \%$ of $\Delta \mathrm{Q} /-100 \mathrm{~mm}$ of $\Delta \mathrm{P}$. On the other hand, $\Delta \mathrm{Q}$ was sensitive to both $\Delta \mathrm{P}$ and $\Delta \mathrm{T}$ under RCP8.5, with a rate of $-6 \%$ of $\Delta \mathrm{Q} /{ }^{\circ} \mathrm{C}$ of $\Delta \mathrm{T}$ and $-11 \%$ of $\Delta \mathrm{Q} /-100 \mathrm{~mm}$ of $\Delta \mathrm{P}$. This procedure was adapted from [24] in an uncertainty runoff study projection in three basins in the USA using $19 \mathrm{CMIP} 5$ models. They demonstrated that $\Delta \mathrm{Q}$ was sensitive to both $\Delta \mathrm{P}$ and $\Delta \mathrm{T}$ for all the studied scenarios.

Moreover, a long-term annual water balance study was carried out to assess the runoff sensitivity to climate changes. One can infer about actual evapotranspiration using basic relations between average annual precipitation and runoff (ET $=$ Precipitation - Runoff). Figure 7 depicts the water balance elements over 30-year periods (time slices) for the GRB-Furnas basin according to the three RCMs, their ensemble, and respective ranges. Eta-HadGEM2-ES and Eta-CanESM2 projected a reduction in precipitation under RCP4.5, followed by a reduction in runoff.

RCP 4.5
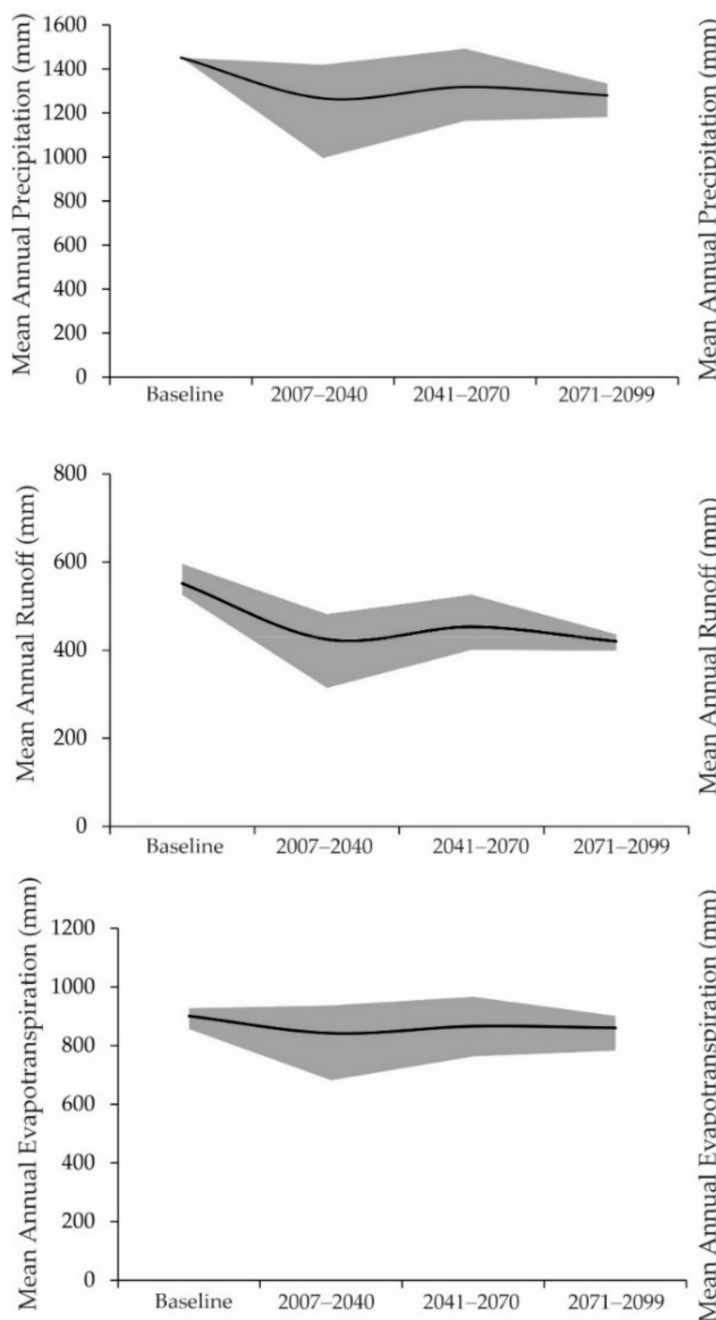

RCP 8.5
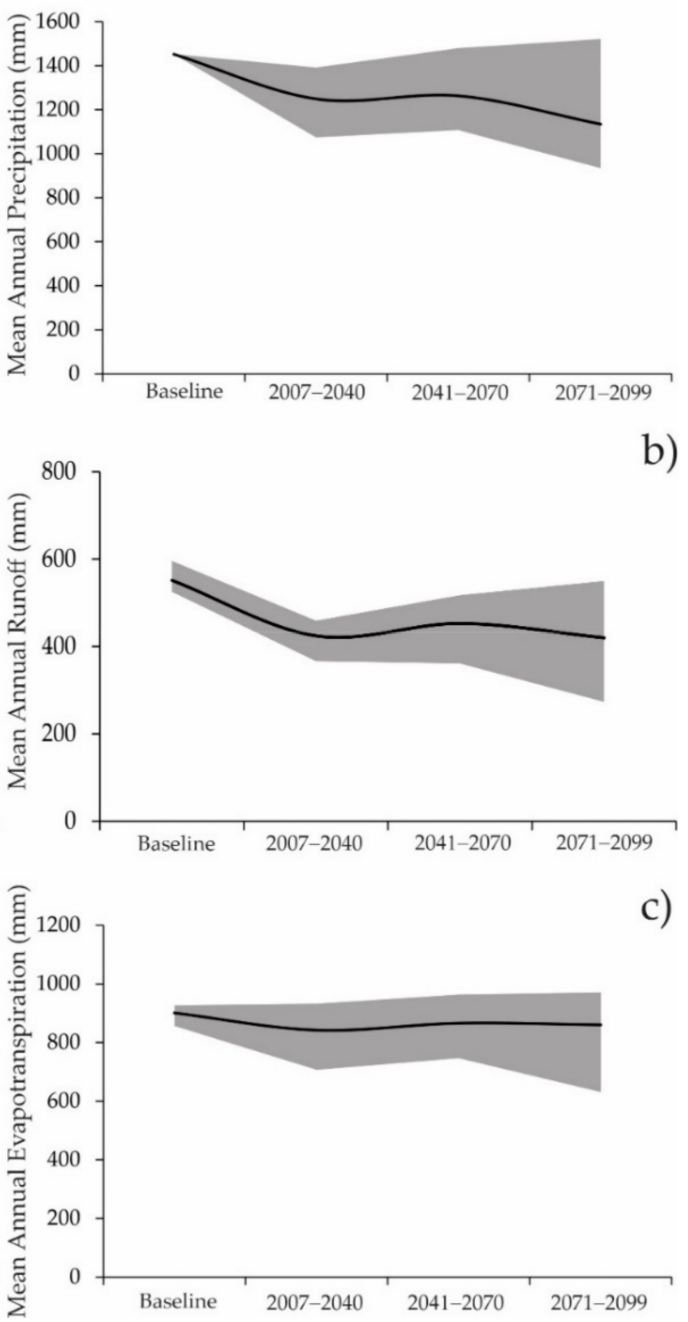

Figure 7. Average annual water balance components for the baseline and time slices simulated by the LASH model forced by the RCMs for the GRB-Furnas basin: (a) precipitation, (b) runoff, and (c) evapotranspiration. 


\subsubsection{Monthly Runoff Projection}

This section presents the performance of the LASH combined with RCMs in simulating the average monthly hydrograph in the baseline (Figure $8 \mathrm{a}$ ) and its projections per time slice and RCP (Figure 8b,c).

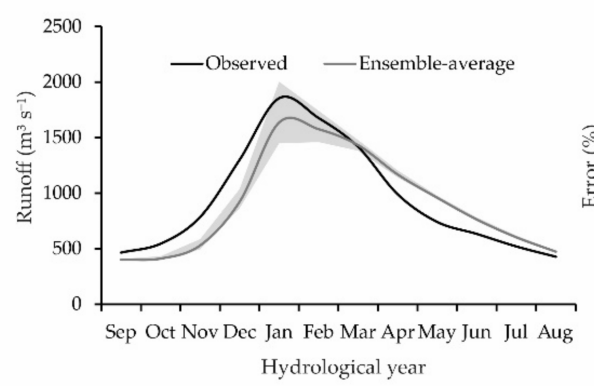

(b)

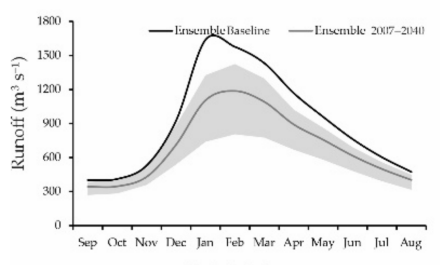

Hydrological year

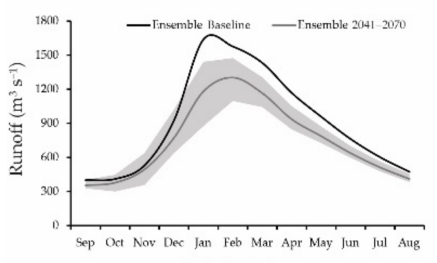

Hydrological year

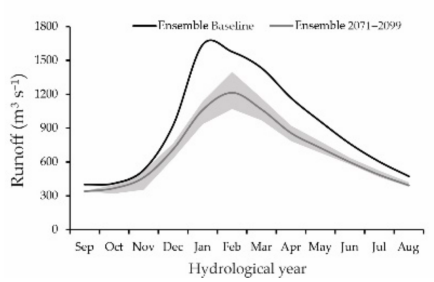

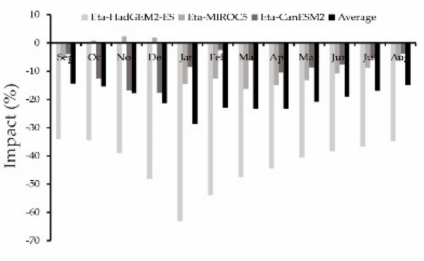
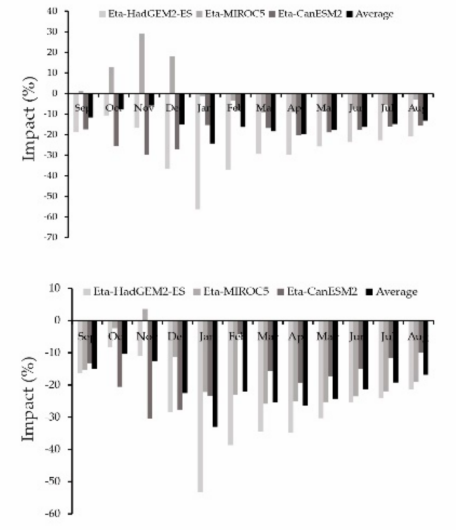

(a)

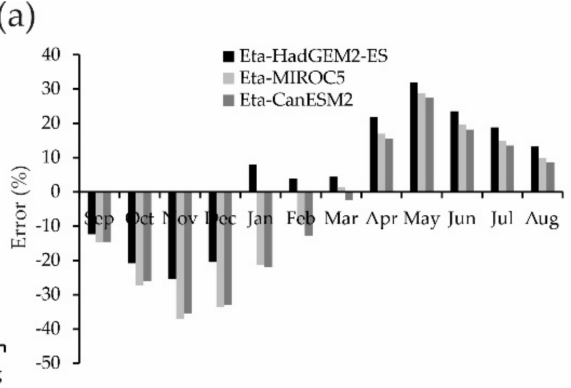

(c)
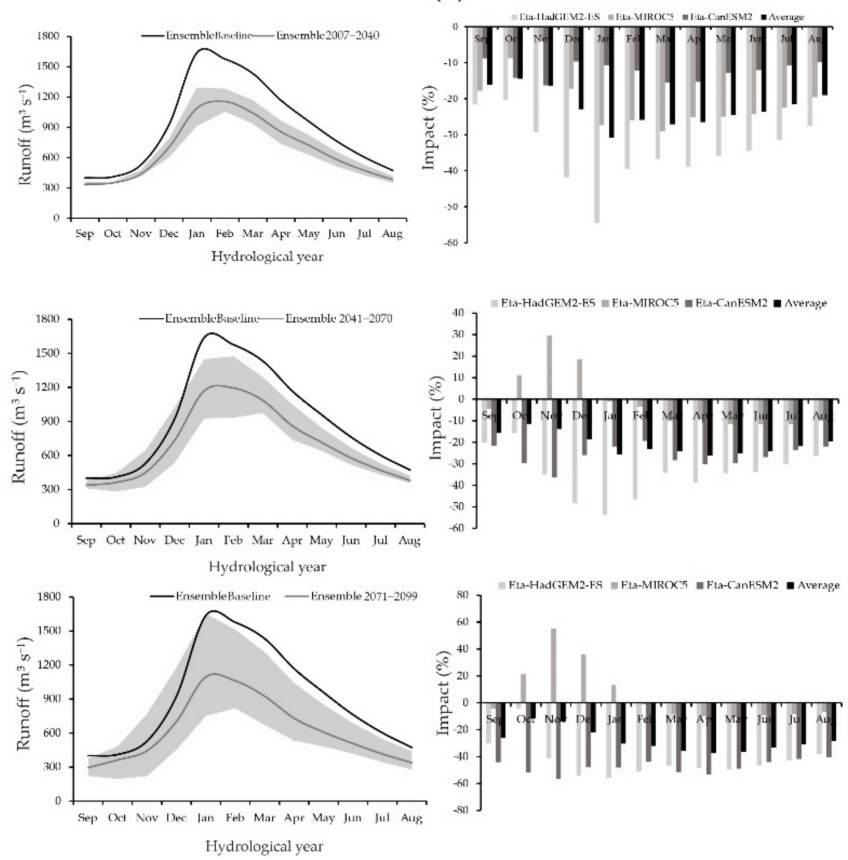

Figure 8. Average observed and simulated (ensemble) monthly hydrograph and respective errors (\%) in the baseline (a) and projections (impacts, in \%) of the RCMs on runoff throughout XXI Century in the GRB-Furnas: (b) RCP4.5 and (c) RCP8.5.

On analyzing the errors ((observed - simulated)/observed) for the entire hydrological year, Eta-HadGEM2-ES, Eta-MIROC5, and Eta-CanESM2 produced average values of $+17 \%$, $-20 \%$, and $-19 \%$, respectively.

\subsubsection{Changes in the Flow Duration Curve (FDC) Indicators}

This section presents how climate change would impact some relevant hydrological indicators extracted from FDC. Figure 9 presents the performance of the LASH model in conjunction with the RCMs in simulating FDC indicators for the GRB-Furnas for the baseline (errors, in \%, regarding the observed values). 


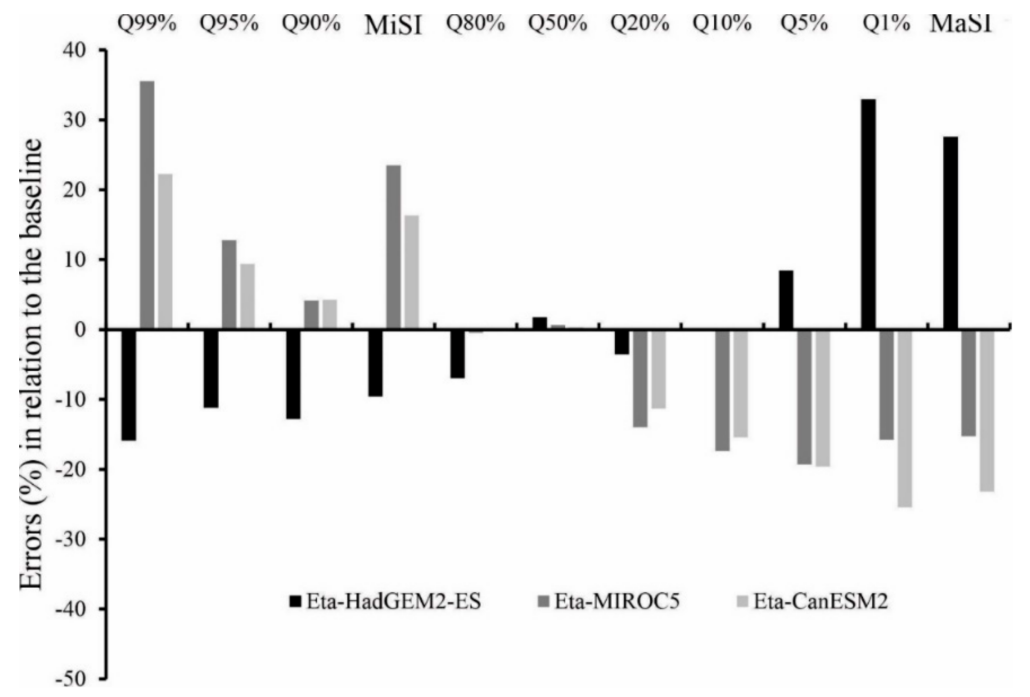

Figure 9. Performance of the LASH model along with the RCMs in simulating the flow duration curve (FDC) indicators for the baseline.

Figure 10 depicts changes in the FDC indicators projected by the RCMs in the three time slices and RCPs.
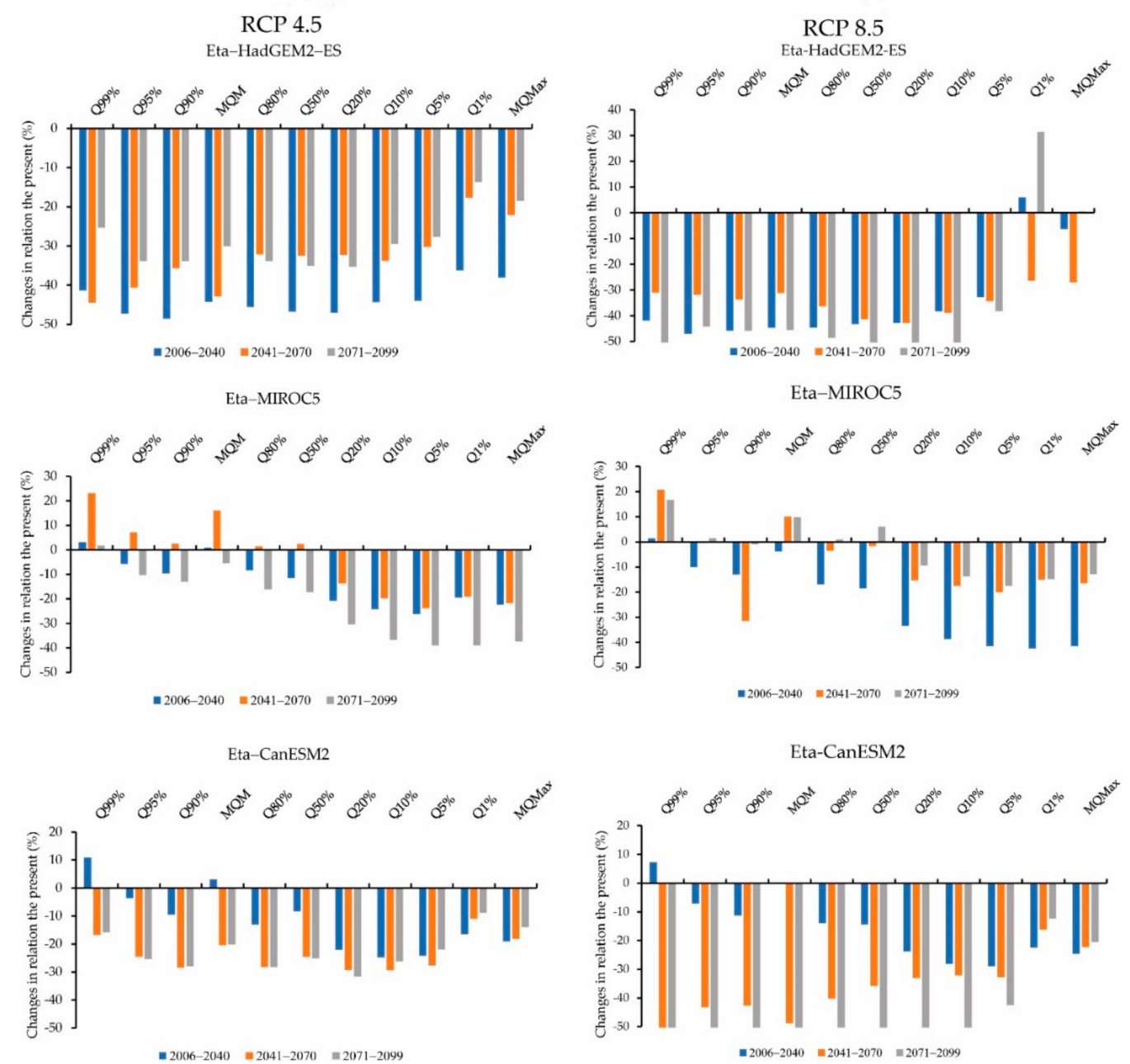

Figure 10. Changes (\%) in the FDC indicators for the GRH-Furnas basin projected by the LASH model combined with the RCMs under RCP4.5 and RCP8.5. 


\subsubsection{Hydrological Drought Assessment}

The Standardized Streamflow Index (SSFI) was studied for the GRB-Furnas basin through the RCMs and LASH model for the baseline period, considering the hydrological year as the time lag for the drought. This index was then projected over the XXI Century. SSFI was obtained from fitting the gamma probability function (GPF) to stationary runoff historical series. Thus, the Mann-Kendall test was applied to the observed and simulated runoff series, representing the baseline. The $p$-value was $0.325,0.094,0.683$, and 0.884 for the observed runoff series and those simulated by LASH forced by Eta-HadGEM2-ES, Eta-MIROC5, and Eta-CanESM2, respectively; i.e., there is no temporal trend. Figure 11 depicts the GPF fitting to the observed and simulated historical series corresponding to the baseline. All the fittings were adequate according to the Anderson-Darling test $(p<0.05)$.

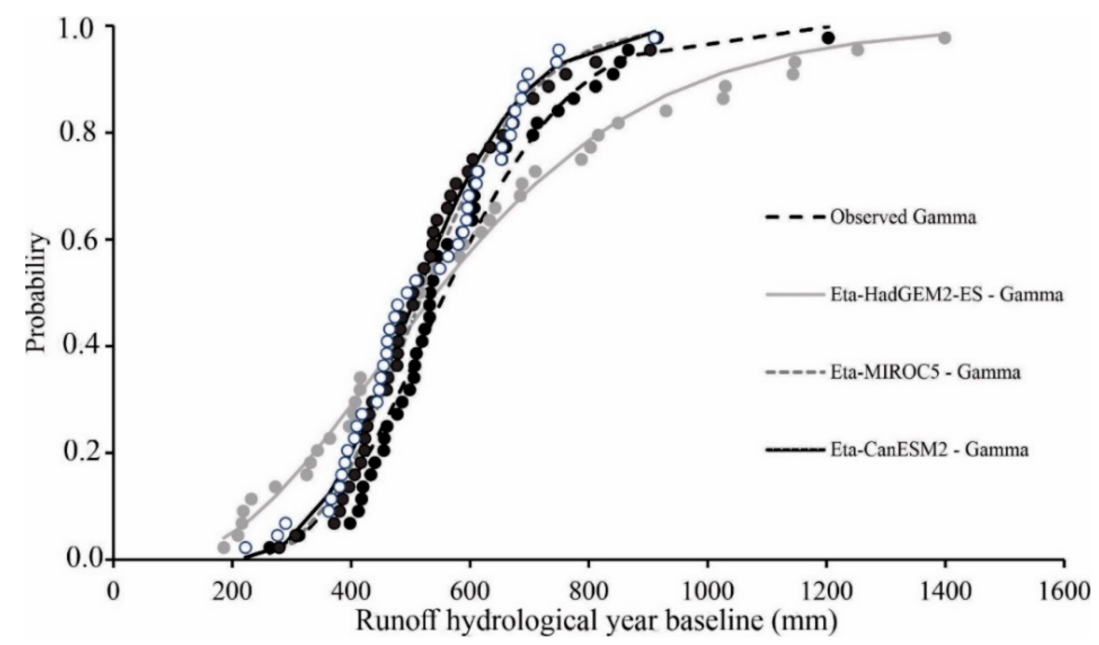

Figure 11. Gamma probability function (GPF) fitted to the observed series and simulated runoff series for the baseline.

The GPF scale and position parameters for the observed runoff series were 11.456 and 50.215, respectively, whereas, for Eta-HadGEM2-ES, these values were 3.907 and 151.7, respectively. On the other hand, Eta-MIROC5 and Eta-CanESM2 simulated historical series closer to the observed series, especially in the extremes, and the GPF fittings were similar (estimated parameters were 13.657 and 39.131, and 13.042 and 40.179, for Eta-MIROC5 and Eta-CanESM2, respectively).

Table 4 shows the SSFI thresholds followed by the respective classification [44] and the runoff and return period calculated for each class for the GRB-Furnas basin.

For the projection of the droughts' return period over the XXI Century, the GPF was fitted to the runoff series simulated by the LASH forced with the RCMs. The MannKendall test was previously applied, which allowed the detection of negative trends in the series resulting from the simulation based on the Eta-CanESM2, whereas the runoff series simulated with data from Eta-HadGEM2-ES and Eta-MIROC5 were stationary (Table 5). Table 5 highlights the projected return period of the SSFI, according to Eta-HadGEM2-ES (only for RCP4.5 because, for RCP8.5, the GPF was not adequate by the Anderson-Darling test) and Eta-MIROC5. 
Table 4. Standardized Streamflow Index (SSFI) thresholds and classification, and runoff and return period (RP) from the observed historical series and simulated series from the RCMs forcing the LASH model.

\begin{tabular}{|c|c|c|c|c|c|c|}
\hline $\begin{array}{c}\text { SSFI } \\
\text { Threshold }\end{array}$ & $\begin{array}{l}\text { Runoff } \\
\text { (mm) }\end{array}$ & Classification & $\begin{array}{l}\text { RP (Years)- } \\
\text { Observed }\end{array}$ & $\begin{array}{l}\text { RP (Years)- } \\
\text { HadGEM2-ES }\end{array}$ & $\begin{array}{l}\text { RP (Years)- } \\
\text { MIROC5 }\end{array}$ & $\begin{array}{c}\text { RP (Years)- } \\
\text { CanESM2 }\end{array}$ \\
\hline$<-2.0$ & $<288$ & ED & 43.6 & 7.3 & 41.6 & 32.5 \\
\hline$-2.0-(-1.5)$ & $288-344$ & SD & 22.8 & 13.8 & 18.8 & 22.5 \\
\hline$-1.5-(-1.0)$ & $344-408$ & MD & 10.8 & 10.8 & 8.6 & 8.6 \\
\hline$-1.0-1.0$ & $408-742$ & $\mathrm{~N}$ & 1.5 & 2.3 & 1.4 & 1.4 \\
\hline $1.0-1.5$ & $742-848$ & MW & 10.8 & 11.6 & 17.0 & 17.0 \\
\hline $1.5-2.0$ & $848-962$ & VW & 22.7 & 15.4 & 49.6 & 49.6 \\
\hline$>2.0$ & $>962$ & EW & 43.7 & 8.7 & 158.1 & 158.1 \\
\hline
\end{tabular}

Table 5. Return period (years) for the droughts in the hydrological years projected by the Eta-HadGEM2-ES and Eta-MIROC5 coupled to the LASH model in the GRB-Furnas.

\begin{tabular}{|c|c|c|c|}
\hline \multirow{2}{*}{ SSFI Classification } & \multirow{2}{*}{$\begin{array}{c}\text { Eta-HadGEM2-ES } \\
\text { RCP4.5 * }\end{array}$} & \multicolumn{2}{|c|}{ Eta-MIROC5 } \\
\hline & & $\mathrm{RCP} 4.5 * *$ & RCP8.5 *** \\
\hline Extremely Dry & 2.4 & 10.0 & 9.8 \\
\hline Severely Dry & 8.7 & 9.5 & 10.0 \\
\hline Moderately Dry & 8.7 & 6.4 & 6.9 \\
\hline Normal & 3.4 & 1.8 & 1.8 \\
\hline Moderately Wet & 35.4 & 23.7 & 19.6 \\
\hline Very Wet & 61.9 & 59.1 & 43.6 \\
\hline Extremely Wet & 63.9 & 135.0 & 81.9 \\
\hline
\end{tabular}

* M-K $p$-value: $0.403 ;{ }^{* *}$ M-K $p$-value: $0.119 ;{ }^{* * *}$ M-K $p$-value: 0.079.

\section{Discussion}

The five main sub-basins (Figure 3) drain an average annual water volume to the Furnas reservoir of approximately $11.65 \mathrm{~km}^{3}$. In these sub-basins, the baseflow is the dominant runoff component (the average $\mathrm{B} / \mathrm{R}$ is 0.594 , varying from 0.530 to 0.680 ). This means that these sub-basins have a strong natural hydrological regularization, with a high potential for water yield, which has been explored especially for hydroelectricity in the Grande river basin [10] (Figure 1). In general, these sub-basins display almost the same evapotranspiration behavior, which is, on average, approximately $830 \mathrm{~mm}$ annually. They are located predominantly in the headwaters of GRB-Furnas, which is an area less impacted by anthropogenic actions in terms of land-use change [8]. However, the authors of [5] detected relevant climate change impacts caused by a significant reduction in precipitation projected throughout the XXI Century, which was also observed in this study. Therefore, one of the most relevant strategies to mitigate climate change in the GRB-Furnas consists of avoiding land-use changes, mainly deforestation of Atlantic Forest.

The observed and calculated volume ratio $(\Delta \mathrm{V}$, Table 3$)$ is an index that describes the model capability in the simulation of the water balance, reflecting on evapotranspiration estimates [8]. A slight overestimation of the evapotranspiration was observed, which does not compromise the water balance simulated over the studied period [3]. According to [45] there is no threshold for this statistic that allows classifying a continuous hydrological model, which essentially depends on the study's purposes. A great accuracy of the model is highlighted by the agreement between estimated and observed hydrographs, including daily peak flows and baseflow. This feature has a key role in evaluating whether the hydrological model can simulate the basins' hydrological cycle [45]. 
In Brazil, other hydrological simulation studies have used naturalized streamflow [5,7,46-48]. The authors of [5] used monthly naturalized streamflow to calibrate the SWAT model and assess the climate change impacts on hydropower generation of three facilities in the Upper Grande river basin. They found satisfactory results (NSC ranging from 0.53 to 0.74 ). The authors of [7] calibrated the MGB-IPH model on a monthly basis to study impacts on hydropower plants' generation in GRB. These authors obtained NSC and log (NSC) ranging from 0.85 to 0.95 , similar to the present study. In the cited studies, the hydrological models were classified as "good" and reliable for predicting runoff over the century.

The time series of precipitation and evapotranspiration in the rainy period (OctoberMarch) for the four weather stations in the GRB-Furnas showed no precipitation trend in any of them in the last 58 years. For evapotranspiration, which is influenced, among other elements, by temperature, one can observe an increasing trend for three of the four locations, meaning a possible increase in temperature, especially in the last two decades. However, for one of these locations (São Lourenço-station 3), there was no trend in evapotranspiration. São Lourenço is the smallest city of the four studied, located at $953 \mathrm{~m}$ southwest of station 3 , resulting in a reduced urban impact compared with the warmer climate observed in the other stations. The increase in their urban area might help explain the increased evapotranspiration provoked by an increase in temperature in these locations. However, the main cause of the reduction in streamflow was linked to the reduction in precipitation, especially for RCP4.5. Note that this impact has not been observed across the last 58 years of precipitation records. Furthermore, seasonally, in the last decade (2010-2020), the records indicate a reduction in the total precipitation during the rainy period, as observed by [49] for Lavras (station 1). This impact might reflect changes in the precipitation regime due to climate change over the region.

Reductions in the wet season were predominantly projected by the RCMs, which means that the models converged towards a reduction in precipitation throughout the century. In the dry season, the RCMs projected an increase with a range that encompasses the highest positive and lowest negative changes due to the RCM's different behavior, resulting in increased uncertainty. The most severe reductions in precipitation were projected by Eta-HadGEM2-ES and Eta-CanESM2 in both RCPs during the first time slice, with more uncertainties for RCP8.5. In general, precipitation changes on a regional scale have been projected by RCMs with more uncertainties than other climate variables in several world regions [24], affecting the planning for water security in the future.

In the second time slice, precipitation reduction in the wet season is lower than projected for the first time slice. In the dry season, such changes are slight, almost constant in both RCPs. It was found that precipitation would tend to increase for November, independently of the RCM or RCP projection. This was explained to be due to the projected increase in the temperatures for October and November (Figure $6 b, c)$, leading to a greater convection activity, favoring cloud formation, and an increase in rainfall. It is likely that this period would be the most prone to natural hazards in the region in the future.

Regarding the maximum and minimum temperatures (Figure $6 b, c)$, the RCP ensembles indicate an increase of approximately $2{ }^{\circ} \mathrm{C}$ across all months during 2007-2040. More severe changes are expected in the third time slice (2071-2099) according to RCP8.5, with increases of approximately $7{ }^{\circ} \mathrm{C}$ in the maximum average monthly temperatures and $4{ }^{\circ} \mathrm{C}$ in the minimum temperatures. The range for minimum temperature in both the second and third time slices under RCP8.5 is smaller than that for maximum temperature, leading to less uncertainty of the RCMs.

Eta-HadGEM2-ES and Eta-CanESM2 projected a warmer climate than Eta-MIROC5 throughout the XXI Century in the GRB-Furnas. Eta-MIROC5 projected an increase of $2.0^{\circ} \mathrm{C}$ in both maximum and minimum temperatures according to RCP4.5, whereas under $\mathrm{RCP} 8.5$, such temperatures were increased by $3.0^{\circ} \mathrm{C}$ and $4.0^{\circ} \mathrm{C}$, respectively. Eta-CanESM2 projected a warmer climate than the other RCMs, with respect to maximum and minimum temperatures of $9.0^{\circ} \mathrm{C}$ and $5^{\circ} \mathrm{C}$ in RCP8.5. The authors of [31] observed that Eta-HadGEM2ES projections were more sensitive than those generated by Eta-MIROC 5 concerning the 
increase of greenhouse emissions in South America. However, they did not study the Eta-CanESM2, and little is known about this RCM in Brazil. Thus, increases in temperature and reduction in precipitation may negatively impact the water security and management of the FHP reservoir in this century.

In RCP8.5, $\Delta \mathrm{Q}$ had a significant influence on $\Delta \mathrm{T}$ because, in this scenario, global warming will continuously increase up to the end of the century, making the increases in temperature more relevant than those identified in RCP4.5. In RCP4.5, the temperature tends to stabilize from the middle to the end of the century, which can explain why $\Delta \mathrm{Q}$ had been less affected by an increase in temperature. In this study, a coefficient of correlation $(p<0.05)$ between $\Delta \mathrm{Q}$ and $\Delta \mathrm{P}$ was determined, varying from 0.920 (Eta-MIROC5) to 0.956 (Eta-CanESM2), and between $\triangle \mathrm{Q}$ and $\triangle \mathrm{ET}$ (changes in evapotranspiration) from -0.591 (Eta-MIROC5) to -0.809 (Eta-CanESM2). These results indicate that $\Delta \mathrm{Q}$ is more sensitive to $\Delta \mathrm{P}$ in tropical basins. Although $\Delta \mathrm{Q}$ was less (or non) significant to $\Delta \mathrm{T}$, the relevance of evapotranspiration should be highlighted as the coefficient of correlation was statistically significant in all the RCMs.

A more significant reduction was observed from baseline to the 2007-2040 time slice when Eta-HadGEM2-ES was considered. In RCP8.5, increases in annual precipitation were projected, which culminated at the end of the century approximately to the observed value in the baseline and the runoff. Actual evapotranspiration calculated from the water balance is practically the same over the time slices, independently of the RCM or RCP. This finding supports the hypothesis that changes in precipitation exert more influence on runoff in the GRB-Furnas than changes in temperature. Although evapotranspiration is a function of weather elements, it seems that its impact on runoff is limited. This aspect was explained by the reduction in precipitation, limiting soil water storage and then actual evapotranspiration. Overall, this study demonstrates that $\Delta \mathrm{T}$ tends to be less relevant for the water balance in tropical basins under climate change scenarios.

Broader ranges for precipitation projected at the end of the century under the RCP8.5 had more uncertainty [50], with a variation of $350 \mathrm{~mm}$, increasing the uncertainties on runoff projections, and thus water security for the FHP reservoir. In RCP4.5, more uncertainties were identified in the first time slice (2007-2040), for which Eta-HadGEM2-ES projected a greater reduction in precipitation and broader ranges for runoff.

Analyzing runoff behavior in the baseline (Figure 8), the ensemble overestimated runoff from April to August, which was observed when LASH was forced with all the RCMs, especially by Eta-HadGEM2-ES. Opposite behavior was observed between September and February, over which runoff was underestimated for all the RCMs, especially by Eta-MIROC5, which produced the greatest errors. The errors were too small in March, with a slight overestimation by Eta-HadGEM2-ES $(<5 \%)$. Overall, the RCMs indicate a decrease in precipitation during the rainy period and an increase during the dry period, which led to the behavior of the errors displayed in Figure 6a. However, simulations during the rainy season were subjected to higher variability than during the dry season. Several climate phenomena influence the southeast part of Brazil during spring and summer, such as the South Atlantic Convergence Zone; cold fronts; convective rainfalls; and, for the studied basin, an orographic influence. These seasonal climate drivers may result in more significant precipitation simulation errors propagating to streamflow simulation [5], as indicated by weather forecasting models in the region.

LASH forced by the RCMs underestimated the annual runoff, with small differences among them. These errors were smaller than those obtained by [3], using LASH forced with Eta-HadCM3 (A1B SRES scenario and $40 \mathrm{~km}$ spatial resolution) in the Upper Grande river basin. They reported errors of $-21.6 \%,-12 \%,-25 \%$, and $-29 \%$ for four basins in the Upper Grande river, covering approximately $16,000 \mathrm{~km}^{2}$ (Figure $1 \mathrm{~b}$ ).

Errors between simulated and observed monthly hydrographs are expected owing to the use of RCMs as inputs in the hydrological models. RCMs may not precisely reproduce the observed values, with deviations in both magnitude and time, especially the peak flows and baseflow. The physical structure of the RCMs, parametrizations, downscaling 
technique, RCPs, and sensitivity of the runoff to climate variables are the primary sources of uncertainties $[24,51,52]$. Besides, uncertainties regarding the hydrological model calibration may provoke differences between observed and simulated hydrographs. LASH was calibrated and validated between 1990 and 2007 and forced by the RCMs' outputs spanning to the baseline period (1961-2006), i.e., an extended period (1961-1989) was completely unknown for the model. Despite these uncertainties, LASH forced by the RCMs in the baseline period demonstrated acceptable performance for reproducing the average runoff, in consonance with other studies $[3,5,53]$.

The monthly runoff simulated by LASH forced with the RCMs' projections might be significantly reduced throughout the XXI Century (Figure $8 b, c)$. Projections using EtaHadGEM2-ES caused the most significant reductions. In the first time slice (2007-2040) under RCP4.5 (Figure 8b), the reduction in runoff was up to $63 \%$ (January) and, in the second (2041-2070) and third (2071-2099) times slices, it was $-56 \%$ and $-50 \%$, respectively.

Reductions in runoff were also observed when evaluating Eta-MIROC5, although in a different manner. In RCP4.5, the highest reduction was observed in March for the third time slice $(-26 \%)$. Based on RCP8.5, the highest projected reduction was in the first time slice (-29\% in March). This RCM was the only one that projected a small increase in the runoff at the end of the century, following the precipitation pattern in this RCP (Figure 7).

Eta-CanESM2 under RCP4.5 projected a reduction in the runoff; however, it was less noticeable when compared with Eta-HadGEM2-ES. The most significant reductions were projected for the second and third time slices. On the other hand, under RCP 8.5, reductions were more highlighted and similar to those projected by Eta-HadGEM2-ES.

Further analyzing the runoff reduction, the most significant changes could be observed for RCP4.5 in the first time slice and for the RCP8.5 in the third time slice (Figure 8b,c). The average observed runoff during the wet season (November-March) in the baseline was $316.5 \mathrm{~mm}$. For the first situation, the ensemble was $237.3 \mathrm{~mm}(-25 \%)$. However, this value is expected to vary from $170.6 \mathrm{~mm}(-46.1 \%)$ to $273 \mathrm{~mm}(-13.7 \%)$. This means that, even considering the upper limit, the projected runoff would tend to a reduction, i.e., a clear signal of the reduction in water availability, with implications for the operation and management of the FHP reservoir. Regarding the second situation (RCP8.5; third time slice), the ensemble projected a runoff of $220.8 \mathrm{~mm}(-30.2 \%)$, representing a greater impact than RCP4.5 in the first time slice. However, a broader range was projected with runoff values varying from $158.1 \mathrm{~mm}(-50 \%)$ to $333.6 \mathrm{~mm}(+5.4 \%)$, meaning more uncertainties in the projections under RCP8.5 towards the end of the century.

We discussed that runoff would tend to a reduction over the century. However, how this reduction could affect specific discharges that are used to define the water availability and then water rights and floods in the basin needs to be further detailed.

A more significant uncertainty was found for the lowest and the highest daily streamflow values (i.e., $\mathrm{Q}_{99 \%}$ and $\mathrm{Q}_{1 \%}$, respectively) (Figure 9). Eta-HadGEM2-ES underestimated $\mathrm{Q}_{99 \%}$ by $15 \%$ and overestimated $\mathrm{Q}_{1 \%}$ by 33\%. The other RCMs gave opposite projections, i.e., they overestimated $\mathrm{Q}_{99 \%}$ and underestimated $\mathrm{Q}_{1 \%}$. The RCMs well projected the average minimum streamflow indicator (MiSI). However, for the MaSI indicator, the performance of the RCMs was inferior. Eta-HadGEM2-ES overestimated it by approximately $30 \%$, whereas Eta-CanESM2 underestimated it by $25 \%$. Other FDC indicators were reasonably well estimated by the RCMs, especially for frequencies between $20 \%$ and $80 \%$. The average errors accounting for all the FDC indicators were $0.96 \%,-0.51 \%$, and $-3.25 \%$ by Eta-HadGEM2-ES, Eta-MIROC5, and Eta-CanESM2, respectively.

In general, all the models projected a reduction in the lowest streamflows (baseflow) concerning the baseline (Figure 10), which implies constraining water availability in the dry season. Among the RCMs, however, this projection was variable. Eta-HadGEM2-ES projected the greatest changes in the baseflow for the first time slice (2006-2040) under RCP4.5 owing to the reduction in precipitation in the wet season, while under RCP8.5, the impacts were more highlighted in the third time slice, especially in the case of Eta-CanESM2. 
Eta-MIROC5 projected a reduction in the highest streamflows (from $\mathrm{Q}_{50} \%$ ), mostly in the third time slice (2070-2099) under RCP4.5, whereas for RCP8.5, such changes were markedly in the first time slice (2006-2040). Eta-MIROC5 suggested that baseflow would be less affected than Eta-HadGEM2-ES, with $\mathrm{Q}_{99 \%}$ and MiSI displaying a slight increase under RCP4.5 for the second time slice (Figure 10). In RCP8.5, these indicators showed similar changes; however, more were highlighted in the second and third time slices. MaSI had an increase of $10 \%$ in these time slices, which is a reflex of the projected increase in the precipitation towards the end of the century under RCP8.5.

Eta-CanESM2 projected, overall, a reduction in FDC indicators, but less pronounced in RCP4.5 when compared with RCP8.5 (Figure 8). This RCM under RCP8.5 projected the greatest reduction in the MiSI, especially in the second and third time slices, thus severely impacting baseflow.

Therefore, the most severe impact on runoff was projected to significantly reduce the baseflow over the XXI Century, potentially compromising the water security and management of the FHP reservoir.

Droughts are meteorological events that can be boosted by climate change, impacting all of society and the management of the environment. Thus, their study can quickly generate a useful background for water security strategies. Besides, this analysis demonstrates the capabilities of a hydrological model combined with RCMs to simulate SSFI, especially events with greater severity, as they potentially impact society, economy, and the environment. Therefore, SSFI was firstly detailed for the observed hydrograph in the baseline, calculating the return period and respective runoff value. These values were taken as a reference for evaluating the $\mathrm{RCMs}^{\prime}$ capability for simulating the frequency of hydrological droughts.

It is clear that Eta-HadGEM2-ES under- and overestimated the runoff compared with the observed series, thereby leading to a different fit of the GPF, especially for the lowest and highest runoff values (Figure 11). Eta-MIROC5 showed better performance for the projection of severe droughts (i.e., $\mathrm{ED}, \mathrm{SD}$, and $\mathrm{MD}$ ), with a return period similar to that determined from the observed runoff. Eta-CanESM2 also provided good performance for such events, while Eta-HadGEM2-ES demonstrated poor performance. This behavior can be explained based on the performance of the RCMs coupled with the hydrological model in simulating the streamflows in the dry period (between April and August) (Figure 8a). LASH model forced with the outputs from Eta-CanESM2 and Eta-MIROC5 produced these values in a more accurate way than Eta-HadGEM2-ES, with errors varying from 6-7\% (in August) to 25-27\% (in May), while Eta-HadGEM2-ES generated 12\% and 33\%, respectively. As the lowest streamflow values characterize severe hydrological droughts, it is expected that these RCMs would simulate a historical series closer to the observed one, as can be seen in Figure 11, explaining their better performance for hydrological droughts' study in the GRB-Furnas. In contrast, all the RCMs demonstrated poor performance for predicting extreme wet years. Eta-MIROC5 and Eta-CanESM2 underestimated (greater return period), whereas Eta-HadGEM2-ES overestimated (lower return period) the frequency of occurrence. The RCMs well estimated the "normal" years.

The most significant errors occurred owing to (i) the RCMs resulted in a SSFI drought classified oppositely to the SSFI based on the observed runoff; (ii) the RCMs over or underestimated the droughts; and (iii) the RCMs classified a given event as the observed, but with an opposite signal of SSFI. Such errors were mainly observed for Eta-HadGEM2-ES.

Firstly, one can observe that both RCMs projected the droughts with a smaller return period (greater frequency) than the baseline. Eta-HadGEM2-ES projected an ED event approximately every two years, whereas Eta-MIROC5 projected it every ten years. The second observation is that MW and VW years would be scarce, especially when considering the Eta-HadGEM2-ES projections and EW years by Eta-MIROC5 projections.

The results obtained in this study have limitations because they are grounded in simulations, which always have uncertainties. However, they revealed a change mainly in the precipitation pattern, and the primary consequence is a significant change in the runoff, 
with an increase in severe droughts in this century. Therefore, the GRB-Furnas basin and FHP reservoir should be prepared for a significant reduction in water availability, which harms the water security and environment management of this country's strategic region.

\section{Conclusions}

This study assessed the impacts of climate change on the GRB-Furnas basin's hydrological response, in southeast Brazil. Daily and monthly streamflow simulations were performed using the LASH model. The main findings are as follows:

(i) LASH model simulations for the calibration and validation periods (1991-2007) were in good agreement with observations (NSC of $0.86, \log$ (NSC) of 0.83 , and $\Delta \mathrm{V}$ of $2.16 \%$, respectively, in a daily time step).

(ii) The RCMs projected significant changes in the GRB-Furnas climate throughout the $21 s t$ century, negatively impacting the runoff. In general, future scenarios project a decrease in precipitation during the wet season, which is expected to lead to a significant decrease in runoff and, therefore, in water surplus in the GRB-Furnas basin.

(iii) Future LASH simulations indicated that runoff changes are expected to be more sensitive to changes in precipitation under the RCP4.5 projection rather than the RCP8.5 projection.

(iv) LASH simulated a reduction in runoff associated with a further decrease in baseflow contribution. Eta-HadGEM2-ES and Eta-CanESM2 projected the most significant reduction in the runoff, especially in the wet period. The former RCM, in RCP4.5, projected a more significant reduction in the first time slice (2007-2040), whereas the latter RCM projected a more severe impact for RCP8.5 in the third time slice (2071-2099).

(v) Eta-MIROC5 showed superior performance regarding drought studies; in general, the RCMs' projections indicate a likely increase in the frequency occurrence of severe hydrological droughts and a likely reduction in the occurrences of wet hydrological years.

(vi) The projections of climate change over the tropical regions in South America have shown a reduction in precipitation, mostly in the rainy season, and the consequences of this impact on water resources may be deeply drastic for such regions. The results of this study can be used as a reference in terms of the pattern of the water cycle in the basins located in southeast and middle-west regions, with a significant concentration of hydropower plants, where water demand has increased significantly for irrigation purposes.

Author Contributions: Conceptualization, C.R.M.; methodology, C.R.M., M.R.V. and N.P.A.V.; software, N.P.A.V. and M.R.V.; validation, C.R.M., N.P.A.V. and S.B.; formal analysis, C.R.M., J.A.G. and M.R.V.; resources, C.R.M.; data curation, N.P.A.V., C.R.M., M.R.V. and L.A.A.; writing-original draft preparation, C.R.M., J.A.G. and S.B.; visualization, C.R.M., L.A.A. and J.A.G.; supervision, C.R.M.; project administration, C.R.M.; funding acquisition, C.R.M. All authors have read and agreed to the published version of the manuscript.

Funding: This research was funded by CNPq (Grant number 301556/2017-2), FAPEMIG (Grand number PPM 545-18), and CAPES for doctorate scholarship to the second author.

Institutional Review Board Statement: Not applicable.

Informed Consent Statement: Not applicable.

Data Availability Statement: The study did not report any data.

Conflicts of Interest: The authors declare no conflict of interest. 


\section{References}

1. Intergovernmental Panel on Climate Change (IPCC). Climate Change 2013: The Physical Science Basis; Cambridge University Press: Cambridge, UK, 2013; Available online: http:/ /www.ipcc.ch/report/ar5/wg1/ (accessed on 8 February 2016).

2. Lubini, A.; Adamowski, J. Assessing the Potential Impacts of Four Climate Change Scenarios on the Discharge of the Simiyu River, Tanzania Using the SWAT Model. Int. J. Water Sci. 2013, 2, 1-12. [CrossRef]

3. Viola, M.R.; Mello, C.R.; Chou, S.C.; Yanagi, S.N.; Gomes, J.L. Assessing climate change impacts on Upper Grande River Basin hydrology, Southeast Brazil. Int. J. Climatol. 2015, 35, 1054-1068. [CrossRef]

4. van Vliet, M.T.H.; Wiberg, D.; Leduc, S.; Riahi, K. Power-generation system vulnerability and adaptation to changes in climate and water resources. Nat Clim. Chang. 2016, 6, 375-381. [CrossRef]

5. Oliveira, V.A.; Mello, C.R.; Viola, M.R.; Srinivasan, R. Assessment of climate change impacts on streamflow and hydropower potential in the headwater region of the Grande river basin, Southeastern Brazil. Int. J. Climatol. 2017, 37, 5005-5023. [CrossRef]

6. Bueno, E.O.; Alves, G.J.; Mello, C.R. Hydroelectricity water footprint in Parana hydrograph region, Brazil. Renew. Energy 2020, 162, 596-612. [CrossRef]

7. Nóbrega, M.T.; Collischonn, W.; Tucci, C.E.M.; Paz, A.R. Uncertainty in climate change impacts on water resources in the Rio Grande Basin, Brazil. Hydrol. Earth Syst. Sci. 2011, 15, 585-595. [CrossRef]

8. Viola, M.R.; Mello, C.R.; Beskow, S.; Norton, L.D. Impacts of land-use changes on the hydrology of the Grande river basin headwaters, Southeastern, Brazil. Water Resour. Manag. 2014, 28, 4537-4550. [CrossRef]

9. Mello, C.R.; Norton, L.D.; Curi, N.; Yanagi, S.N.M. Sea surface temperature (SST) and rainfall erosivity in the Upper Grande River Basin, Southeast Brazil. Ciência Agrotecnologia 2012, 36, 53-59. [CrossRef]

10. Mello, C.R.; Viola, M.R.; Norton, L.D.; Silva, A.M.; Weimar, F.A. Development and application of a simple hydrologic model simulation for a Brazilian headwater basin. Catena 2008, 75, 235-247. [CrossRef]

11. Beskow, S.; Mello, C.R.; Norton, L.D.; Silva, A.M. Performance of a distributed semi-conceptual hydrological model under tropical watershed conditions. Catena 2011, 86, 160-171. [CrossRef]

12. Beskow, S.; Mello, C.R.; Norton, L.D. Development, sensitivity and uncertainty analysis of LASH model. Sci. Agric. 2011, 68, 265-274. [CrossRef]

13. Caldeira, T.L.; Mello, C.R.; Beskow, S.; Timm, L.C.; Viola, M.R. LASH hydrological model: An analysis focused on spatial discretization. Catena 2019, 173, 183-193. [CrossRef]

14. Andrade, N.P.V.; Viola, M.R.; Beskow, S.; Caldeira, T.L.; Guo, L.; Mello, C.R. Assessment of Spatial and Temporal Soil Water Storage Using a Distributed Hydrological Model. Water Resour. Manag. 2020, 34, 1-16. [CrossRef]

15. Mishra, S.K.; Singh, V.P.; Sansalone, J.J.; Aravamuthan, V. A modified SCA-CN method: Characterization and testing. Water Resour. Manag. 2003, 17,37-68. [CrossRef]

16. Novák, V.; Hlaváciková, H. Applied Soil Hydrology, 2nd ed.; Springer International Publishing: Cham, Switzerland, 2019; Volume 342. [CrossRef]

17. Cunge, J.A. On the Subject of a flood propagation computation method (Musklngum Method). J. Hydraul. Res. 1969, 7, 205-230. [CrossRef]

18. Allen, R.G.; Pereira, L.S.; Raes, D.; Smith, M. Crop Evapotranspiration: Guidelines for Computing Crop Water Requirements; Irrigation and Drainage; Paper No. 56; FAO: Rome, Italy, 1998; 328p.

19. Viola, M.R.; Mello, C.R.; Beskow, S.; Norton, L.D. Applicability of the LASH model for hydrological simulation of the Grande River Basin, Brazil. J. Hydrol. Eng. 2013, 18, 1639-1652. [CrossRef]

20. Beskow, S.; Norton, L.D.; Mello, C.R. Hydrological Prediction in a Tropical Watershed Dominated by Oxisols Using a Distributed Hydrological Model. Water Resour. Manag. 2013, 27, 341-363. [CrossRef]

21. Guilhon, L.G.F.; Rocha, V.F.; Moreira, J.C. Comparação de métodos de previsão de vazões naturais a aproveitamentos hidroelétricos. RBRH 2007, 12, 13-20.

22. Müller, I.I.; Rizzi, N.E.; Fill, H.D. Avaliação da vazão indisponibilizada por usinas hidrelétricas em bacias hidrográficas e a cobrança pelo uso da água no setor elétrico. Floresta 2011, 41, 737-750. [CrossRef]

23. Nash, J.E.; Sutcliffe, J.V. River flow forecasting through conceptual models part I: A discussion of principles. J. Hydrol. 1970, 10, 282-290. [CrossRef]

24. Lehner, F.; Wood, A.W.; Vano, J.A.; Lawrence, D.M.; Clark, M.P.; Mankin, J.S. The potential to reduce uncertainty in regional runoff projections from climate models. Nat Clim. Chang. 2019, 9, 926-933. [CrossRef]

25. Xu, C.Y.; Singh, V.P. Review on Regional Water Resources Assessment Models under Stationary and Changing Climate. Water Resour. Manag. 2004, 18, 591-612. [CrossRef]

26. Tan, M.L.; Ibrahim, A.L.; Yusop, Z.; Chua, V.P.; Chan, N.W. Climate change impacts under CMIP5 RCP scenarios on water resources of the Kelantan River Basin, Malaysia. Atmos. Res. 2017, 189, 1-10. [CrossRef]

27. Ouyang, F.; Zhu, Y.; Fu, G.; Lü, H.; Zhang, A.; Yu, Z.; Chen, X. Impacts of climate change under CMIP5 RCP scenarios on streamflow in the Huangnizhuang catchment. Stoch. Environ. Res. Risk Assess. 2015, 29, 1781-1795. [CrossRef]

28. Kopytkovskiy, M.; Geza, M.; McCray, J.E. Climate-change impacts on water resources and hydropower potential in the Upper Colorado River Basin. J. Hydrol. Reg. Stud. 2015, 3, 473-493. [CrossRef]

29. Ho, J.T.; Thompson, J.R.; Brierley, C. Projections of hydrology in the Tocantins-Araguaia Basin, Brazil: Uncertainty assessment using the CMIP5 ensemble. Hydrol. Sci. J. 2016, 6, 1-17. [CrossRef] 
30. Riquetti, N.B.; Mello, C.R.; Beskow, S.; Viola, M.R. Rainfall erosivity in South America: Current patterns and future perspectives. Sci. Total Environ. 2020, 724, 138315. [CrossRef]

31. Chou, S.C.; Lyra, A.; Mourão, C.; Dereczynski, C.; Pilotto, I.; Gomes, J.; Bustamante, J.; Tavares, P.; Silva, A.; Rodrigues, D.; et al. Assessment of Climate Change over South America under RCP 4.5 and 8.5 Downscaling Scenarios. Am. J. Clim. Chang. 2014, 3, 512-525. [CrossRef]

32. Chou, S.C.; Lyra, A.; Mourão, C.; Dereczynski, C.; Pilotto, I.; Gomes, J.; Bustamante, J.; Tavares, P.; Silva, A.; Rodrigues, D.; et al. Evaluation of the Eta Simulations Nested in Three Global Climate Models. Am. J. Clim. Chang. 2014, 3, 438-454. [CrossRef]

33. Chou, S.C.; Marengo, J.A.; Lyra, A.A.; Sueiro, G.; Pesquero, J.F.; Alves, L.M.; Kay, G.; Betts, R.; Chagas, D.J.; Gomes, J.L.; et al. Downscaling of South America present climate driven by 4-member HadCM3 runs. Clim. Dyn. 2011, 38, 635-653. [CrossRef]

34. Watanabe, M.; Suziki, T.; O'ishi, R.; Komuro, Y.; Watanabe, S.; Emori, S.; Takemura, T.; Chikira, M.; Ogura, T.; Sekiguchi, M.; et al. Improved Climate Simulation by MIROC5: Mean States, Variability, and Climate Sensitivity. J. Clim. 2010, 23, 6312-6335. [CrossRef]

35. Collins, W.J.; Bellouin, N.; Doutriaux-Boucher, M.; Gedney, N.; Halloran, P.; Hinton, T.; Hughes, J.; Jones, C.D.; Joshi, M.; Liddicoat, S.; et al. Development and evaluation of an Earth-System model-HadGEM2. Geosci. Model Dev. 2011, 4, 1051-1075. [CrossRef]

36. Martin, G.M.; Bellouin, N.; Collins, W.J.; Culverwell, I.D.; Halloran, P.R.; Hardiman, S.C.; Hinton, T.J.; Jones, C.D.; McDonald, R.E.; O'Connor, F.M.; et al. The HadGEM2 family of Met Office Unified Model climate configurations. Geosci. Model Dev. 2011, 43, 723-757. [CrossRef]

37. Lyra, A.; Tavares, P.; Chou, S.C.; Sueiro, G.; Dereczynski, C.P.; Sondermann, M.; Silva, A.; Marengo, J.; Giarolla, A. Climate change projections over three metropolitan regions in Southeast Brazil using the non-hydrostatic Eta regional climate model at 5-km resolution. Theor Appl Climatol. 2018, 29, 663-682. [CrossRef]

38. Cousino, L.K.; Becker, R.H.; Zmijewski, K.A. Modeling the effects of climate change on water, sediment, and nutrient yields from the Maumee River watershed. J. Hydrol. Reg. Stud. 2015, 4, 762-775. [CrossRef]

39. Oliveira, V.A.; Mello, C.R.; Beskow, S.; Viola, M.R.; Srinivasan, R. Modeling the effects of climate change on hydrology and sediment load in a headwater basin in the Brazilian Cerrado biome. Ecol. Eng. 2019, 133, 20-31. [CrossRef]

40. Graham, L.P.; Andréasson, J.; Carlsson, B. Assessing climate change impacts on hydrology from an ensemble of regional climate models, model scales and linking methods-A case study on the Lule River basin. Clim. Chang. 2007, 81, 293-307. [CrossRef]

41. Berg, P.; Feldmann, H.; Panitz, H.J. Bias correction of high resolution regional climate model data. J. Hydrol. 2012, 448, 80-92. [CrossRef]

42. Teutschbein, C.; Seibert, J. Bias correction of regional climate model simulations for hydrological climate-change impact studies: Review and evaluation of different methods. J. Hydrol. 2012, 456, 12-29. [CrossRef]

43. Shrestha, M.; Acharya, S.C.; Shrestha, P.K. Bias correction of climate models for hydrological modelling-are simple methods still useful? Meteorol. Appl. 2017, 24, 531-539. [CrossRef]

44. Junqueira, R.; Viola, M.R.; Mello, C.R.; Vieira-Filho, M.; Alves, M.V.G.; Amorim, J.S. Drought severity indexes for the Tocantins River Basin, Brazil. Theor. Appl. Climatol 2020, 141, 465-481. [CrossRef]

45. Dawson, C.W.; Abrahart, R.J.; See, L.M. HydroTest: A web-based toolbox of evaluation metrics for the standardised assessment of hydrological forecasts. Environ. Model Softw. 2007, 22, 1034-1052. [CrossRef]

46. Matheussen, B.; Kirschbaum, R.L.; Goodman, I.A.; Donnell, G.M.O.; Lettenmaier, D.P. Efects of land cover change on streamflow in the interior Columbia River Basin (USA and Canada). Hydrol. Process. 2000, 14, 867-885. [CrossRef]

47. Weedon, G.P.; Prudhomme, C.; Crooks, S.; Ellis, R.J.; Folwell, S.S.; Best, M.J. Evaluating the Performance of Hydrological Models via Cross-Spectral Analysis: Case Study of the Thames Basin, United Kingdom. J. Hydrometeorol. 2015, 16, 214-231. [CrossRef]

48. Foy, C.; Arabi, M.; Yen, H.; Gironás, J. Multisite Assessment of Hydrologic Processes in Snow-Dominated Mountainous River Basins in Colorado Using a Watershed Model. J. Hydrol. Eng. 2015, 20, 20. [CrossRef]

49. Rodrigues, A.F.; Mello, C.R.; Nehren, U.; Ribeiro, J.P.C.; Mantovani, V.A.; Mello, J.M. Modeling canopy interception under drought conditions: The relevance of evaporation and extra sources of energy. J. Environ. Manag. 2021, 292, 112710-14. [CrossRef]

50. Harding, B.; Wood, A.W.; Prairie, J.R. The implications of climate change scenario selection for future streamflow projection in the Upper Colorado River Basin. Hydrol. Earth Syst. Sci. 2012, 16, 3989-4007. [CrossRef]

51. Amorim, P.B.; Chaffe, P.B. Towards a comprehensive characterization of evidence in synthesis assessments: The climate change impacts on the Brazilian water resources. Clim. Chang. 2012, 36, 53-59. [CrossRef]

52. Prudhomme, C.; Davies, H. Assessing uncertainties in climate change impact analyses on the river flow regimes in the UK. Part 2 : Future climate. Clim. Chang. 2009, 93, 197-222. [CrossRef]

53. Mohor, G.S.; Rodríguez, D.A.; Tomasella, J.; Siqueira Junior, J.L. Exploratory analyses for the assessment of climate change impacts on the energy production in an Amazon run-of-river hydropower plant. J. Hydrol. Reg. Stud. 2015, 4, 41-59. [CrossRef] 